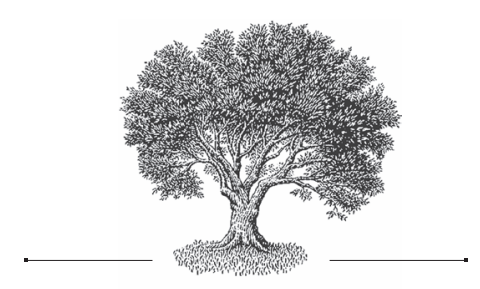

\section{Что такое история языка?*}

\section{Ирина Александровна Подтергера}

Фрайбургский университет им. Альберта и Людвига (Фрайбург в Брайсгау)

\title{
What Is Language History?
}

Irina A. Podtergera

Albert Ludwig University of Freiburg (Freiburg i. Br.)

\section{Резюме}

Статья посвящается понятию 'история языка', которое в российской научной традиции имеет иное наподнение, чем в западноевропейской. Она начинается с рассмотрения современных западноевропейских концепций, согласно которым в истории языка следует видеть историческую дисциплину и отличать ее от исторической грамматики. Предметом истории языка с позиций социопрагматического подхода является в первую очередь история коммуникации. Данный подход представлен в первой части статьи. В дальнейшем ходе исследования акцент делается на истории понятия. Дихотомия 'история языка' vs. 'историческая дингвистика' не является абсолютно новой, а восходит к дихотомии 'внешняя и внутренняя история языка', которая была распространена в конце XIX - начале XX в. и до сих пор сохраняет свою актуальность. Во второй части статьи делается попытка соотнести славистические историкоязыковые штудии последней трети XIX - первых десятилетий XX в. с современными им западноевропейскими историко-языковыми концепциями именно в свете модели 'внешняя и внутренняя история языка'. Особенный интерес в

* Работа выполнена в рамках докторантской программы им. М. К. Врангель, поддерживаемой Министерством науки и культуры земли Баден-Вюрттемберг (Margarete von Wrangell-Habilitationsprogramm für Frauen, gefördert duch das Ministerium für Wissenschaft, Forschung und Kunst Baden-Württemberg).

В данной статье принята следующая система метаязыковых обозначений: курсивом выделяются термины, в одинарные, так наз. марровские, кавычки заключаются понятия, в двойных кавычках приводятся лексические значения и цитаты. Все переводы, если это специально не оговаривается, принадлежат автору статьи. 
этой связи представляет интерпретация понятия 'литературный язык'. В трудах историков языка конца XIX - начала XX в. оно было равнозначным понятию 'письменный язык', т. е. язык письменности вообще. Феномен 'письменный язык' составлял один из аспектов 'внешней истории языка'. В теории функциональной лингвистики, разработанной Пражским лингвистическим кружком, понятие 'литературный язык' получило новое наполнение, а именно 'стандартный язык'. Однако в дингвистической науке советского периода для нового понятия был использован старый термин, за употреблением которого стояла иная традиция. Это привело к смешению понятий и смешению предметов исследования: отдельный аспект выделился в самостоятельную дисциплину - историю литературного языка. Закономерным результатом этого смешения стало сужение области научных интересов. Данной проблеме посвящена третья часть статьи. В заключительной части мы возвращаемся к описанному в начале статьи социопрагматическому подходу к истории языка и предлагаем альтернативную модель для исследования русской языковой истории, которую следует представлять как историю языка и его употребления.

\section{Ключевые слова}

история языка и историческая дингвистика, социопрагматический подход, история коммуникации, внутренняя и внешняя история языка, литературный язык, русская языковая история, исторический язык, история языка и его употребления

\section{Abstract}

This paper examines the notion of 'language history,' which has taken on a different meaning in the Russian linguistic tradition compared to its usage by Western European scholars. The article starts with an analysis of contemporary Western European theories according to which one should consider language history as a historical discipline, and draw a clear distinction between language history and historical grammar. According to the currently accepted socio-pragmatic approach, the subject of language history is, first of all, the history of communication. It is this approach that is presented in the first section of the paper.

The history of this notion is then further analyzed. The dichotomy between 'language history' vs. 'historical linguistics' is not entirely new but goes back to the dichotomy between 'external' and 'internal' language history, which was widespread at the end of the 19th and the beginning of the 20th centuries and still remains important. In the second section, the author compares linguistic studies in the sphere of historical Slavic studies from the last third of the 19th to the first decades of the 20th centuries to the contemporary theories in Western European historical linguistics in the context of the model of external and internal language history.

It is the interpretation of the notion 'literary language' that is of special interest. In the works of historians of language from the late 19th-early 20th centuries, it was used interchangeably with the term 'written language,' i.e., the language of writing in general. The phenomenon of 'written language' constituted an aspect of the 'external history of a language.' In the theory of functional linguistics developed by the Prague linguistic circle, the notion of the 'literary language' acquired a new meaning, i.e., 'standard language.' However, in Soviet linguistics the new concept was denoted by the old term with a different tradition behind it. This led to a confusion regarding the concepts and the subjects of research: the separate 
aspect split off to form a new discipline-the history of literary language-which inevitably resulted in a reduced field of research. This matter is examined in the third segment of the paper.

The concluding section returns to the socio-pragmatic approach to the history of language described at the beginning of the paper, suggesting an alternative model for the study of Russian language history, which should be regarded as the history of language and its usage.

Keywords

language history and historical linguistics, socio-pragmatic approach, history of communication, internal and external language history, 'literary language,' Russian language history, 'historical language,' history of language and its speakers

Вынесенный в название предлагаемой статьи вопрос далеко не тривиальный, и лингвисты уже не однажды задавались им. Так, например, итальянский романист и медиевист Альберто Варваро посвятил специальное исследование понятию 'история языка', называя его спорной категорией (“una categoria controversa”) [VÁRVARO 1972-1973: 16] ${ }^{1}$. В качестве эпиграфа к своему исследованию А. Варваро выбрал цитату из работ известного итальянского лингвиста Джакомо Девото: "Che cosa si intenda per storia di una lingua in generale, e per storia di una lingua particolare come la latina o l’italiana, non è chiaro senz'altro (= Что понимается под историей языка вообще, а также под историей конкретного языка, как, например, латинский или итальянский, конечно, не ясно)" [DEvoto 1940: 371; 1951: 3] (цит. по [VáRVARo 1972-1973: 16]). В контексте нашего исследования особенное значение имеет утверждение А. Варваро, что

... la stessa categoria di 'storia della lingua' appare incerta ed opinabile, e deve essere meglio definita rispetto a categorie come 'grammatica storica' e 'linguistica diacronica' o a quella, più generale, di 'linguistica storica' (= эта самая категория 'история языка' является неясной и спорной и должна быть точнее определена по отношению к таким категориям, как 'историческая грамматика' и 'диахронная лингвистика' или же еще более широко 'историческое языкознание') [IBID.].

В отечественной лингвистике под историей языка в первую очередь понимается развитие звукового, грамматического и лексического состава языка. То есть история языка приравнивается к исторической фонетике, исторической диалектологии, исторической грамматике и исторической лексикологии. Такое понимание истории языка как самостоятельной дисциплины представлено, например, в классическом труде Николая Дурново “Очерк истории русского языка”:

1 На данную работу обратил мое внимание профессор кафедры славянской филологии Удинского университета (Италия) Джорджо Дзиффер (Giorgio Ziffer), за что я ему искренне признательна. 
История языка, изучающая его развитие с момента его образования за всё время существования языка, показывает, что всякий живой язык, т. е. такой язык, который является разговорным языком какого-нибудь народа или общества, непременно изменяется с течением времени; меняется произношение, грамматические формы и значения слов; некоторые прежние звуки, формы, слова исчезают и заменяются новыми [Дурново 1924/1962: 5].

В наши дни понятие ‘история языка’ получило еще более узкое значение: оно зачастую приравнивается только к исторической грамматике, частью которой является историческая фонетика. Об этом свидетельствуют, например, актуальный учебник для высшей школы “История русского языка” В. В. Колесова [Колесов 2005] и одноименное “Учебное пособие для практических занятий” Ю. Г. Захаровой [ЗАХАРовА 2012]. Их содержание составляют: (1) фонология, (2) морфология имени, (3) морфология глагола и (4) синтаксические явления (ср. [КолЕсов 2005: 667669]). При этом В. В. Колесов убежден в том, что “«История русского языка» описывает все аспекты, уровни и стороны исторически развивающегося языка, кроме лексики и словообразования. ..” [ТАм жЕ: 8].

В. В. Колесов осознает недостаточность такого подхода к предмету, но считает невозможным осветить в рамках одного курса все языковые аспекты:

Термин “историческая грамматика” достался нам по наследству от тех времен научного изучения языка, когда лингвисты ставили перед собой задачу восстановить идеальный тип древнерусского [. . .] языка. Сегодня термин устарел и используется по привычке как обозначение традиционного университетского курса, который преподается почти два века. Более правильным было бы говорить об “Истории русского языка” во всем объеме его изменений, но для этого пришлось бы описывать исчерпывающе все уровни языка, включая лексику; кроме того, пришлось бы описывать и те аспекты языка, которые связаны с исторической диалектологией, исторической стилистикой и историей литературного языка (риторика и поэтика художественного текста и проблемы нормы) [TAм жЕ].

Поэтому он предпочитает оставаться в рамках традиционного подхода: “Итак, историческая грамматика как история русского языка" [ТАМ жЕ; курсив автора. - И. П.].

Содержательно иной подход к предмету предлагает Б. А. Успенский. Он делит историю языка на две дополняющие друг друга части:

История языка - в частности, история русского языка - распадается на две взаимодополняющие части: историческую диалектологию и историю л и те ратурного языка. Эти дисциплины до некоторой степени соотносятся с основными источниками по истории языка: памятниками письменности и диалектологическими данными. Это две принципиально разные области, которые отличаются не только объектом, но и методикой исследования. [. . .] [И]стория литературного языка - это история н о р м ы [УСпЕнский 2002: 7; разрядка автора. - И. П.] 
Несмотря на разницу в подходах к предмету исследования истории языка как научной дисциплины, оба они базируются на понимании языка как грамматической системы и на понимании истории как процесса развития и последовательного изменения чего-либо (ср. [БАС, 7: 467]). Однако слово история имеет еще одно значение, а именно: “происшедшее”, т. е. все то, что имело место, или, более конкретно, “совокупность фактов, событий, в жизни кого-, чего-л.”, но также “описание, изложение таких фактов, событий” [там же: 468]. В языке же, как известно, следует видеть не только грамматическую систему, но еще и явление общественной жизни. Такое понимание истории и языка является определяющим в исследовании истории языка в современной западноевропейской лингвистике. Однако примечательно, что оно красной нитью проходит и в трудах патриархов отечественной палеославистики.

Цель настоящей статьи - обратить внимание исследователей на этот альтернативный подход, показать, как вписываются в традицию такого понимания предмета славистические штудии, и представить возможные перспективы, которые открываются для изучения русской языковой истории в свете данного подхода.

\section{1. 'История языка' vs. 'историческое языкознание'}

Итак, язык, как известно, является социальным феноменом и существует в обществе, что делает историю языка неотъемлемой частью истории данного общества. Именно поэтому история языка немыслима без истории политики, культуры, религии, экономики, техники, права и т. д. [SCHмIDT 2007: 1]. Это представление на протяжении уже более ста лет определяет развитие западноевропейской лингвистической историографии. Оно лежит в основе крупнейшего компендиума XX в., задавшего направление дальнейшим историко-языковым исследованиям - тринадцатитомной “Истории французского языка от истоков до наших дней”, инициированной Фердинандом Брюно ("Histoire de la langue française. Des origines à nos jours”, 1906-1953; ее 2-е, переработанное и дополненное издание увидело свет в 1966-1972 гг.) [BRUNOT 1966-1972]. Этот монументальный труд до сих пор остается базовым в романистике и во многих отношениях непревзойденным в других филологиях [HAFNER 2006]. На этой же идее базируется “История языка объединенной Италии” Туллио Де Maypo (“Storia linguistica dell'Italia unita”, 1963) [DE MAURo 1986] - концептуально новая работа, с появлением которой связывают смену парадигм в осмыслении процессов историко-языкового развития: итальянский лингвист вывел этапы и особенности истории языка из контекста социально-политической и экономической истории государства 
[ERNST ET AL. 2003: 7; GiovanARDi 1999: 17]. Тот же концепт стал исходным пунктом для Дика Лита, автора первой социальной истории английского языка (“A Social History of English”, первое издание вышло в 1983 г.). Основная идея этой книги: “The language had changed, that is to say, because it had been made to function in a different kind of society (= Язык изменился, то есть он стал функционировать в другом типе общества)” [LEITH 1997: 8].

Событием в лингвистической историографии последнего десятилетия XX в. стала трехтомная "История немецкого языка от позднего Средневековья до наших дней” Петера фон Поленца (“Deutsche Sprachgeschichte vom Spätmittelalter bis zur Gegenwart”, первое издание вышло в 1991 г., второе, переработанное и дополненное, - в 2000) [VoN PoLENZ 1991-1994]. Немецкий германист, по сути, отталкивается от того же самого концепта, однако значительно развивает его с позиций актуальных достижений лингвистической, филологической и вообще гуманитарной науки. Новизна его концепции заключается прежде всего в том акценте, который ученый делает на историю коммуникации, ставя развитие языковых фактов в прямую зависимость от развития коммуникативных потребностей. Исходным пунктом такого подхода служит противопоставление истории языка и исторической лингвистики: современный филолог, стоящий перед необходимостью осмыслить и обобщить весь накопленный научный опыт, должен разграничивать историю языка и историческую лингвистику / историческое языкознание как две самостоятельные дисциплины:

[Es bedarf...] einer Auffassung von Sprachgeschichte, die über bloße his t o r is ch e Ling u is tik hinausgeht und auf historische Zusammenhänge zwischen Sprache und Gesellschaft im Rahmen kommunikativer Praxis hinweist. Nicht jede diachronische Sprachforschung ist schon Sprachgeschichte (= требуется [. . .] концепция истори и языка, которая перешагнет границы чисто истори ческой лингв истики и перенесет внимание на исторические связи между языком и обществом в рамках коммуникативной практики. Не всякое диахронное исследование языка уже является историей языка) [IвID., 1: 9; разрядка автора. - И. П.].

Задача исторической лингвистики, которую составляют историческая фонетика, историческая грамматика (морфология и синтаксис) и историческая лексикология, - это прежде всего

... frühere Sprachzustände als Systeme und als Inventare von Einzelfakten möglichst umfassend zu beschreiben, z. B. in historischen Grammatiken oder historischen Wörterbüchern, die dem Verständnis, der philologischen Erklärung und Aufbereitung von Texten aus früheren Zeit dienen (= максимально всеобъемлющее описание состояния языка на более ранних стадиях его развития как системы и как инвентаря 
отдельных данных, например, в исторических грамматиках и исторических словарях, которые служат пониманию, филологическому объяснению и публикации текстов более раннего времени) [IBID.].

Тогда как история языка - а в качестве синонимов этого понятия фон Поленц употребляет также выражения историография языка и лингвистическая историография (об этих терминах см. ниже, гл. 4) - концептуально и методологически сходна с исторической наукой resp. историографией ${ }^{2}$ :

Ähnlich wie man in der Geschichtsschreibung - im Unterschied zu Chroniken, Annalen und Regesten - aus den Ergebnissen der historischen Quellenforschung diejenigen Themen und Fakten auswählt und zielgerichtet anordnet, die für langfristige Entwicklungen als wichtig und folgenreich erkannt werden, so hat auch Sprachgeschichtsschreibung aus der Ergebnissen der historischen Sprachforschung diejenigen Bereiche auszuwählen, die sich für die Entwicklung einer Sprache - als Sprachfähigkeit und Sprachpraxis ihrer Benutzer(gruppen) - als wesentlich erweisen. Dieses Auswählen und Erklären ist unvermeidlich verbunden mit dem Wagnis des Bewertens, Hervorhebens, Gewichtens und des Behauptens oder Wahrscheinlichmachens kausaler Zusammenhänge zwischen Sprache und außersprachlichen Faktoren (= Подобно тому как в историографии - в отличие от хроник, анналов, регестов - из результатов исторического источниковедения выбираются и целенаправленно упорядочиваются те темы и факты, которые признаются за важные и имеющие большие последствия для длительных периодов развития, точно так же и в истории языка из результатов исторического языкознания следует отбирать те области, которые оказываются существенными для развития языка как развития языковых возможностей и языковой практики отдельных пользователей этим языком и целых групп его пользователей. Этот отбор и объяснение неизбежно связаны с риском оценить, подчеркнуть, придать значение и признать за правильные или сделать вероятными причинные связи между языком и внеязыковыми факторами) [IBID., 1: 9-10].

\section{Подобным образом немецкий романист Йорн Альбрехт утверждает, что}

[d]ie Sprachgeschichte betrachtet die Sprache als „soziale Institution“. Sie stützt sich selbstverständlich auf die Erkenntnisse der historischen Grammatik, betrachtet jedoch darüber hinaus noch ganz andere Bereiche: Die Veränderungen des geographischen Geltungsbereichs einer Sprache; die Bemühungen um die Normierung der Sprache; die Auswirkungen der allgemeinen politischen Ereignisse auf das Leben der Sprache und nicht zuletzt die Literatur aus sprachlichem Blickwinkel. Kurz und gut, sie ist der sprachspezifische Teil der allgemeinen Ideen- und Kulturgeschichte einer Sprachgemeinschaft, in der Regel später einer Nation (= история языка рассматривает язык как “социальную практику” [букв.: “институцию”]. Само собой разумеется, что она опирается на накопленный опыт исторической грамматики, однако помимо того она рассматривает и совершенно иные области знания: изменения географического ареала

2 Тем самым получает воплощение идея, которую А. Варваро считал трудноосуществимой на практике, см. [VÁRVARo 1972-1973: 16, прим. 2]. 
распространения языка, усилия по нормированию языка, влияние общеполитических событий на жизнь языка и не в последнюю очередь литературу под языковым углом зрения. Короче говоря, история языка - это специфически языковая часть общей духовной и культурной истории определенного языкового сообщества, которое, как правило, впоследствии стало нацией) [ALBRECHT 2003: 7].

Концепция, согласно которой история языка, имея предметом своего исследования историю коммуникации, отделяется от исторического языкознания и причисляется к историческим наукам, является определяющей в современной западноевропейской филологии, прежде всего у представителей немецкой филологической школы и в первую очередь у германистов и романистов ${ }^{3}$. С одной стороны, она отчасти дублирует хорошо известное разделение истории языка на внутреннюю и внешнюю; с другой - представляет собой следующий этап научных осмыслений, этап, подключающий к уже существующей и оправдавшей себя традиции актуальное научное знание. Детерминантами этого знания выступают накопленный за вторую половину XX столетия опыт (исторической) социолингвистики и “прагматический переворот” в языкознании. Результатом интереса к этим направлениям стало расширение сферы историко-языковых исследований до истории культуры в широком смысле слова, т. е. в том числе до истории интеллектуальной культуры, и до собственно истории, а также осмысление истории языка как истории коммуникативных форм и коммуникативного поведения.

В самых общих чертах этапы развития современной концепции истории языка обозначены, например, во вступительной статье к сборнику работ участников состоявшейся в Гейдельберге в октябре 1997 г. международной конференции по теме “История языка как история культуры” (“Sprachgeschichte als Kulturgeschichte”) [GARDT ET AL. 1999]. Здесь же дается дефиниция понятию ‘история языка’:

Bis in die sechziger Jahre des 20. Jahrhunderts hinein war die Sprachgeschichtsschreibung weitgehend systemlinguistisch orientiert. [. . .] In den vergangenen drei Jahrzehnten hat die Sprachgeschichtsschreibung damit begonnen, ihren Gegenstandsbereich in die Sozialgeschichte auszuweiten. [ . . .] In der jüngsten Zeit werden nun in der Sprachgeschichtsschreibung Überlegungen angestellt, den historiographischen Gegenstand über die Sozialgeschichte im engeren Sinne in die Kulturgeschichte zu erweitern. [...] Sprachgeschichtsschreibung bedeutet danach, den Wandel sprachlicher Phänomene vor dem Hintergrund der Geschichte u. a. der Philosophie, der Religion, des politischen Denkens, der gesellschaftlichen Institutionen, selbstverständlich auch der Kunst (speziell der Literatur) und der Sozialgeschichte, bis hin zu einer Geschichte der „Mentalitäten“ und einer „Alltagsgeschichte“ zu beschreiben und zu beurteilen.

\footnotetext{
См., например, все статьи в [HSK, 2/1] и раздел “Methodische Grundlagen der romanistischen Sprachgeschichtsschreibung (= Методические основы лингвистической историографии в романистике)" в [HSK, 23/1].
} 
Dabei sind diese Gegenstände und ihre Entwicklungen der Sprache nicht einfach nur vorgegeben, so dass Sprachgeschichte lediglich Spiegel der Kulturgeschichte wäre, sondern sie werden im gesellschaftlichen Diskurs, d. h. indem über sie sprachlich, mittels bestimmter Wörter und Redeweisen gehandelt wird, konstituiert (= Вплоть до шестидесятых годов XX в. история языка была ориентирована в значительной степени на системную лингвистику. [. . .] В последние три десятилетия [т. е. в 1970-е - 1990-е гг. - И. П.] история языка начала расширять область своих исследований, обратившись к социальной истории. [. . .] Сегодня же в лингвистической историографии высказываются мысли о том, чтобы через социальную историю в узком смысле включить в область описаний историю культуры. [. . .] История языка означает в таком случае описание и оценку изменений языковых феноменов в контексте истории и, в частности, в контексте философии, религии, политической мысли, общественных институтов, разумеется, также искусства (особенно литературы) и социальной истории, вплоть до истории “идей” и “истории быта” / “истории повседневности”. Причем эти сферы и их развитие не просто заданы языку наперед, так что история языка была бы лишь зеркальным отражением истории культуры, но они устанавливаются в общественном дискурсе, т. е. за счет того, что их трактуют - с помощью определенных слов и оборотов) [GARDT ET AL. 1999: 1-2].

Эволюция социопрагматического, коммуникативного подхода к истории языка, а также основные положения этого подхода обстоятельно освещаются в работах П. фон Поленца [Von Polenz 1998], Д. Херубима [CHerubiм 1998: 539-541], К.-Й. Маттайера [MATtheier 1998] и др. [ERnst et Al. 2003; Metzeltin/Gritzky 2003; Polzin-Haumann 2006: 1144]. Все эти исследователи - в соответствии с их целями - описывают и систематизируют научный опыт германистики и романистики. Для нас же сейчас первоочередной интерес представляет вопрос о том, как с этим исследовательским контекстом соотносятся славистические историко-языковые штудии.

\section{2. 'Внутренняя' и 'внешняя' история языка}

Как было упомянуто выше, современное разделение понятий 'историческое языкознание' и 'история языка' накладывается на прежнее разделение истории языка на внутреннюю и внешнюю. При этом надо отметить, что, несмотря на то что “новая” дихотомия находит все большее число своих сторонников, соответствующая ей “старая” в силу своей универсальности до сих пор не устарела: с точки зрения содержательного наполнения терминов она эквивалентна “новой”, а потому попрежнему остается в ходу в научном дискурсе.

Разделение истории языка на внутреннюю и внешнюю особенно почитаемо в национальной романской - и прежде всего франкоязычной филологии, что имеет свои объективные причины [BLUMENTHAL 2003]. 
Эта дихотомия, накладываясь на предшествующую ей дихотомию язык и литература ${ }^{4}$, лежит у истоков французской национальной лингвистической историографии. В 1897 г. Гастон Парис, один из крупнейших филологов-медиевистов второй половины XIX в., опубликовал статьюрецензию по поводу выхода в свет первых глав “Истории французского языка” Фердинанда Брюно в рамках масштабного проекта Луи Пети де Жюльвиля "История французской литературы и французского языка" [Brunot 1896A; 1896в; Petit De Julleville 1896]. В своей рецензии Парис описал "le programme d'une histoire pour ainsi dire idéale de la langue française (= программу, так сказать, идеальной истории французского языка)" [PARIS 1897/1909: 179]. Согласно его представлениям, предмет должен делиться на две части: histoire interne и histoire externe ${ }^{5}$. Первая предполагает исследование развития языковой системы:

l'exposition en ordre chronologique des modifications qu'a subies le latin, à partir de son introduction dans l'Ile de France, dans sa phonétique, sa morphologie, son lexique et sa syntaxe (= хронологическое изложение фонетических, морфологических, лексических и синтаксических изменений, которым подверглась латынь с начала ее употребления в исторической области Иль де Франс) [IBID.: 177-178];

вторая - историю французского языкового сообщества: его возникновение, распространение, культурные контакты:

Il faut d'abord déterminer exactement où s'est formé le parler qu'on appelle français [...]; rechercher quand on a commencé de l'écrire; suivre pas à pas les progrès de son extension hors de son domaine primitif, d'abord dans la France du Nord, puis dans celle du Midi, et même en dehors des limites de la France; distinguer si cette extension [. . . ] affecte la langue parlée ou seulement la langue écrite, la langue populaire ou seulement la langue officielle [...]. Enfin à l'histoire externe appartient encore celle des travaux qui ont été accomplis sur la langue, de l'idée qu'on s'en est faite, des institutions qui ont eu pour but d'en activer ou d'en guider les lentes modifications, et du travail considérable accompli par les grammairiens (= Сначала надо точно определить, где сформировалось наречие, именуемое французским, [. . . ] исследовать, когда начали на нем писать, шаг за шагом проследить, как расширялся ареал его употребления за пределами его изначальной области, на севере Франции, затем на юге и даже за границами Франции; выяснить, [. . .] затрагивает ли это расширение язык разговорный или только лишь письменный, язык общеупотребительный

4 См. об этом в [VÁRVARo 1972-1973: 25-28].

5 Многие исследователи, однако, не учитывают рецензии Париса, - не говоря уже о более ранних авторах, речь о которых пойдет ниже, - и возводят эту дихотомию непосредственно к Брюно (см., например, [DROIXHE/DUTILLEUL 1990: 437; Wilmet 1990: 493-494; MetZeltin/GRITZKY 2003: 17]). А. Варваро обращает внимание на то, что у Брюно разделение истории языка на внутреннюю и внешнюю появляется только в четвертом томе его “Истории французского языка”, вышедшем в 1897 г. [VÁRVARo 1972-1973: 29; прим. 68)]. В этом же году вышла и рецензия Париса, посвященная первым двум томам “Истории” Брюно, в которых рассматриваемая дихотомия не упоминается. 
или только язык официальный [. . .]. Наконец, к внешней истории относится еще и история трудов, написанных о языке, история представлений о языке, история учреждений, которые имели своей целью активизировать или направлять постепенные языковые изменения, а также история той огромной работы, которую проделали грамматисты) [IBID.: 178-179].

Эта программа, ставшая сегодня традиционной моделью написания истории языка в романистике ${ }^{6}$ была введена в действие десятилетие спустя (1906 г.), когда начала выходить в свет упомянутая выше многотомная “История французского языка” Брюно”.

Долгожительство предложенной дихотомии было обеспечено не только универсальностью ее характера, но и тем фактом, что она нашла отражение в трудах Фердинанда де Соссюра ${ }^{8}$, разделившего лингвистику на внутреннюю и внешнюю (linguistique interne и linguistique externe) ${ }^{9}$. В сферу исследовательских интересов последней он отнес:

1) ... . tous les points par lesquels la linguistique touche à l'ethnologie, toutes les relations qui peuvent exister entre l'histoire d'une langue et celle d'une race ou d'une civilisation. . . (= все те пункты, в которых языкознание соприкасается с этнографией, все связи, которые могут существовать между историей языка и историей народности или культуры);

2) ... les relations existant entre la langue et l'histoire politique. De grands faits historiques comme la conquête romaine, ont eu une portée incalculable pour une foule de faits linguistiques. [. . .] La politique intérieure des États n’est pas moins importante pour la vie des langues [...]. Un degré de civilisation avancé favorise le développement de certaines langues spéciales (langue juridique, terminologie scientifique, etc.) (= связи,

6 По этой модели построены историко-языковые статьи, например, в таком авторитетном издании, как “Лексикон романского языкознания” / "Lexikon der Romanistischen Linguistik” [LRL:3, 4, 5/1, 5/2, 6/1, 6/2]. Таким же образом организован том [HSK, 23/1], см. здесь статьи № 66-96. В германистике и англистике дихотомия внутренняя и внешняя история языка, будучи хорошо известной, используется, тем не менее, реже.

7 См. современную информацию об истории терминов в [BERSCHIN 2001: 628629; 2003: 33-34]. А. Варваро подчеркивал, что история употребления обоих терминов требует специального исследования [VÁRVARO 1972-1973: 29, прим. 68].

8 Роль, которую сыграл авторитет женевского лингвиста в укреплении этой дихотомии, демонстрирует тот факт, что некоторые исследователи склонны вести традицию разделения истории языка на внутреннюю и внешнюю именно от де Coccюра (см., например, [GoNZÁLEZ 1992: 406-407], а также далее в тексте).

9 Как известно, в 1916 г. был опубликован реконструированный учениками де Соссюра третий из прочитанных им циклов лекций по общему языкознанию, который и цитируется в нашей работе. Однако следует также обратить внимание на то, что в более раннее время де Соссюр также оперировал терминами внутренняя и внешняя история языка [DE SAUSSURE 1996: 105-111]. Об этом свидетельствует публикация законспектированного Альбертом Ридлингером первого цикла соссюровских лекций (1907 г.): “Aperçu sur l'histoire interne et externe de la famille des langues indoeuropéennes (= Замечания к внутренней и внешней истории индоевропейской семьи языков)” [IBID.: 105]. 
существующие между языком и политической историей. Великие исторические события, такие как римское завоевание, имели неисчислимые последствия для огромного числа языковых фактов. [. . .] Внутренняя политика государства не в меньшей степени важна для жизни языков. [. . . ] Развитию некоторых специальных языков (юридического, научной терминологии и т. д.) способствует развитый уровень цивилизации);

3) ... les rapports de la langue avec des institutions de toute sorte, l'Église, l'école, etc. Celles-ci, à leur tour, sont intimement liées avec le développement littéraire d'une langue, phénomène d'autant plus général qu'il est lui-même inséparable de l'histoire politique. La langue littéraire dépasse de toutes parts les limites que semble lui tracer la littérature [...] D'autre part elle pose la grosse question du conflit qui s'élève entre elle et les dialectes locaux [... .]; le linguiste doit aussi examiner les rapports réciproques de la langue du livre et de la langue courante; car toute langue littéraire, produit de la culture, arrive à détacher sa sphère d'existence de la sphère naturelle, celle de la langue parlée (= отношения языка со всевозможными учреждениями: церковью, школой и т. д. Эти последние, в свою очередь, тесно связаны с литературным развитием языка, - феноменом тем более универсальным, что он сам неотделим от политической истории. Литературный язык сплошь и рядом переходит границы, которые ему устанавливает, казалось бы, литература. [. . .] С другой стороны, он остро ставит вопрос о конфликте, который возникает между ним и местными диалектами [. . .]; языковед должен также рассматривать взаимоотношения между книжным и обиходным языками, поскольку всякий литературный язык, будучи продуктом культуры, в процессе своего развития приходит к размежеванию среды своего бытования со средой естественной, то есть со средой разговорного языка);

4) ... tout ce qui se rapporte à l'extension géographique des langues et au fractionnement dialectal (= все то, что относится к географическому распространению языков и к их диалектному разделению) ${ }^{10}$ [DE SAUSSURE 1972: 40-42; нумерация проставлена мной. - И. П.].

Выделение де Соссюром внешней лингвистики соотносилось с его пониманием природы языка [KOEDER 1999: 112-124]: как известно, он называл его “социальным фактом” (fait social); лингвистику же определял как “науку, которая изучает жизнь знаков внутри социальной жизни” (ср.: "une science qui étudie la vie des signes au sein de la vie sociale") [DE SAUSSURE 1972: 33]. Одной из ее задач он считал:

10 Cp. данное место в [DE SAUSSURE 1972: 43-44]. Приводимые здесь и далее цитаты из “Курса общей лингвистики” де Соссюра я сопровождаю собственной версией перевода, представляющей собой переработку классического русского перевода труда де Соссюра, выполненного А. М. Сухотиным (1933 г.) [де Соссюр 2006]. Выполненный, вне всяких сомнений, на высоком профессиональном уровне, данный перевод, тем не менее, не всегда предельно корректен (ср. ниже сноску 16). Кроме того, он несколько архаичен по языку, что в том числе касается ряда современных терминов и терминологических выражений, ср., например, перевод названия курс общей лингвистики, тогда как сегодня принято выражение курс общего языкознания. Однако в рамках данной статьи мы все же сохраним известное читателю русскоязычное название курса Соссюра, с тем чтобы без дополнительных уточнений было понятно, что речь идет именно об этом труде. 
... de chercher les forces qui sont en jeu d'une manière permanente et universelle dans toutes les langues, et de dégager les lois générales auxquelles on peut ramener tous les phénomènes particuliers de l'histoire (= поиск постоянно действующих и универсальных для всех языков сил и выработку общих правил, к которым можно было бы свести все частные процессы истории) [IBID.: 20].

По мнению современного специалиста, авторитет де Соссюра способствовал развитию принципа, свойственного французской филологической традиции, а именно тому, что в рамках этой традиции лингвистика всегда имплицитно подразумевала социолингвистику, а стало быть, и история языка естественным образом подразумевала исследование не только внутренних, системно-языковых особенностей, но и внешних, внеязыковых, социальных [Sснмітт 1999: 69].

Нет оснований сомневаться в том, что Гастон Парис, Фердинанд Брюно и Фердинанд де Соссюр являются теми самыми тремя китами, на которых держится современная национальная лингвистическая историография в романистике. Однако у этих французских (точнее, франкоязычных) филологов и лингвистов рубежа XIX-XX вв. были предшественники, и в том числе - славянские. Так, с разделения истории языка на внутреннюю и внешнюю начинается опубликованная в Лейпциге в 1870 г. русскоязычная магистерская диссертация Яна Бодуэна де Куртенэ “О древнепольском языке до XIV столетия” [BAUDOUIN DE COURTENAY 1974-1990, 2: $1^{11}$ - первого защитившегося докторанта лейпцигского профессора славистики Августа Лескина [RICHTER 1970: 110; MugDAN 1984: 12-13], чьим учеником пять лет спустя станет также Фердинанд де Соссюр. Более подробно данная дихотомия развита в лекции Бодуэна де Куртенэ, которую он прочитал в том же, 1870-м, году в Петербургском университете, вступая в должность приват-доцента (“Некоторые общие замечания о языковедении и языке”; текст впервые был опубликован в 1871 г.). В рамках нашего обзора показательно его обоснование концепта 'внешняя история языка':

Внешняя история языка тесно связана с судьбами его носителей, то есть с судьбами говорящих им индивидуумов, с судьбами народа. В круг ее исследований входит распространение языка, как географическое, так и этнографическое, общее влияние иностранных языков на данный язык и наоборот, решение вопросов, употребляется ли данный язык и как литературный, или же он живет только в народе, каким сословиям принадлежат люди, говорящие известным языком, в большом ли ходу язык (если он, разумеется, литературный) за своими собственными пределами, как по отношению к пространству (французский, немецкий, английский и вообще так называемые универсальные языки), так и по отношению ко времени (латинский, греческий, церковнославянский), и если он в употреблении у других народов, то для каких именно целей, и т. д. и т. д. [. . .] Материал для

11 См. такЖе [ШАРАДЗЕНидЗЕ 1980: 77-78] и [BudziaK 1997: 21-22]. 
внешней истории языка совпадает в значительной степени с материалом для истории и истории литературы. Говоря о распространенности народа, о его образованности, о расцвете его литературы, историк тем самым затрагивает во многих пунктах внешнюю историю языка этого народа [BAUDOUIN DE COURTENAY 19741990, 4: 56, прим. 34].

Приведенная цитата показывает, что Бодуэн де Куртенэ - как и более чем 25 лет спустя Фердинанд де Соссюр - относит к 'внешней истории языка' географический, этнографический, социальный и историкокультурный факторы, а также феномен литературного, т. е. письменного, языка в его отличии от языка разговорного.

Вопрос о том, следует ли связывать введение в научный оборот дихотомии 'внутренняя и внешняя история языка' с именем Бодуэна де Куртенэ или же в этом разделении, скорее, все-таки следует видеть общее место лингвистической мысли конца 1860-х - начала 1870-х гг., требует дополнительных разысканий ${ }^{12}$. Э. Косериу, П. Кох и Р. Баум ведут традицию этой дихотомии не от Бодуэна - его написанные по-русски работы начала 1870-х гг. остались им неизвестными, - а от Георга фон дер Габеленца, чей обобщающий труд “Языкознание: Его проблемы, методы и достигнутые результаты” (“Die Sprachwissenschaft: Ihre Aufgaben, Methoden und bisherigen Ergebnisse”) впервые был опубликован в 1891 г. [VON DER GABELENTZ 1972] ${ }^{13}$. Фон дер Габеленц дал четкую и лаконичную дефиницию понятиям 'внутренняя' и 'внешняя история языка':

Wir werden, um Missverständnisse zu vermeiden, gut thun, zwischen äusserer und innerer Sprachgeschichte zu unterscheiden. Die ä us e re Geschichte einer Sprache ist die Geschichte ihrer räumlichen und zeitlichen Verbreitung, ihrer Verzweigungen und etwaigen Mischungen (G e n e a l o g i e ). Die i n n e r e S p r a c h g e s c h i c h t e erzählt und sucht zu erklären, wie sich die Sprache in Rücksicht auf

12 В российском языкознании принято сегодня аксиоматично утверждать, что автором анализируемой дихотомии является именно Бодуэн де Куртенэ, но при этом не приводится никаких доказательств, подтверждающих это мнение; см. [ЕРОФЕЕВА 2001: 68] - здесь без каких-либо ссылок дословно воспроизводится работа [ШАРАДЗЕНИДЗЕ 1980: 77]; см. также [ЧЕРЕПАНОВ 2003: 31; НИКОЛАЕВА 2003: 22; ЖурАвлЕвы 2005]. Следует, однако, принимать во внимание весь научный контекст того времени. Идея противопоставления “внутреннего” и “внешнего" буквально висела в воздухе. Бодуэн де Куртенэ, например, считал себя преемником идей Вильгельма фон Гумбольдта (см. автобиографические заметки Бодуэна в [ВенгеРов 1897: 29]). Во втор. пол. ХІХ в. достаточно авторитетным оставалось учение фон Гумбольдта о внутренней и внешней форме языка(впервые: 1836 г., а также в последующих работах) [VON HuMBoLDT 1998: 204-219; DICESARE 1998: 85-89]. А. Варваро сопоставляет дихотомию внутренняя и внешняя история языка с дихотомией Вильгельма фон Гумбольдта GeistSprache (дyx/душа - язык) [VÁRVARO 1972-1973: 29-30].

13 CM. [Coseriu 1967/1972: 87; Koch 1988: 343, BAUM 2003: 48-49], cp. [VÁRvARo 1972-1973: 29, прим. 68]. 
Stoff und Form allmählich verändert hat (= Чтобы избежать недоразумений, необходимо различать внутреннюю и внешнюю историю языка. В н е ш н я я и с т о р и я я 3 ы к а - это история его пространственного и временного расширения, его разветвления и возможных смешений (г е н е а л о г и я ). В н у т р е н н я я и с т о р и я я 3 ы к а описывает и пытается объяснить, как язык постепенно изменился с точки зрения содержания и формы) [IBID.: 141-142; разрядка автора. - И. П.] $]^{14}$.

В дальнейшем изложении к внешней истории языка он отнес географический, антропологический, этнографический и культурно-исторический аспекты [IBID.: 142-168]. Туллио Де Мауро (см. в издании [DE SAUSSURE 1972: 428-429]) и Эберхард Гильденбрандт [HILDENBRANDT 1972: 32-34], издатели и комментаторы “Курса общей лингвистики”, считая эту дихотомию, главным образом, открытием де Соссюра (ср. сноску 12), называют в качестве стимулировавшего его предшественника немецкого младограмматика Германа Пауля, провозгласившего лингвистику культурологической дисциплиной. Он не разделял историю языка на внутреннюю и внешнюю, но вслед за Я. Гриммом, Ф. Боппом, В. фон Гумбольдтом, а особенно же А. Шлейхером уподоблял язык биологическому организму (растительному или животному), внутренние качества которого развиваются под внешним влиянием таких факторов, как климат, питание, условия жизни [PAUL 1920: 37-39]. Его книга “Принципы истории языка" (“Principien der Sprachgeschichte”) вышла в свет в 1880 г. в Галле. Однако свою первую ученую степень Пауль, как и Бодуэн де Куртенэ, получил в 1870 г. в Лейпциге ${ }^{15}$. В этой связи наводит на размышления дата, названная де Соссюром в его кратком обзоре этапов истории лингвистических учений: “Ce n'est que vers 1870 qu'on en vint à se demander quelles sont les conditions de la vie des langues (= Только

14 До фон дер Габеленца в немецкой филологической традиции выражение внешняя история языка встречается, например, у романиста Густава Грёбера [GRÖBER 1888в: 415-419], который определяет это понятие как “die Geschichte der Ausbreitung und Verwendung romanischer Sprache (= история распространения и употребления языков в романских странах)” [IBID.: 419] (cp. [VÁRVARO 1972-1973: 29, прим. 68]), но не противопоставляет “внутренней истории языка”. Вместо этого он делает разницу между историческим и генетическим языкознанием [GRÖBER 1888c: 224-250]. Однако с противопоставления внутренней и внешней истории языка начинается опубликованное в том же году исследование швейцарского германиста Адольфа Социна [SocIN 1888: III]. Можно предположить, что Гастон Парис, речь о котором шла выше, заимствовал данную дихотомию именно у немецких филологов: как известно, он был учеником боннского профессора романистики Фридриха Дица, боготворил учителя и делал со своей стороны все возможное, чтобы привить во Франции научные методы и традиции немецкой филологической школы, см. [BÄHLER 2004], а также [БРОКГАУз/ЕФРОН, 22А: 810-811].

15 С Лейпцигским университетом связано, кроме того, имя фон дер Габеленца: в конце 1860 -х гг. он изучал в Лейпциге китайский язык, а в конце 1870-х получил там же первую в Германии кафедру синологии. 
около 1870 г. начали задаваться вопросом, каковы условия жизни языков)” [DE SAUSSURE 1972: 18] ${ }^{16}$.

Интерес для нас представляет перспектива пересечения научных традиций: в XIX - нач. XX в. слависты, германисты и романисты работали в тесном контакте друг с другом. Обращение к исследовательскому опыту разных филологических направлений для патриарха Женевской лингвистической школы имело принципиальное значение ${ }^{17}$. Он не писал научного трактата, его целью было - обобщить в курсе лекций существующее на данный момент развития лингвистической науки знание, выразив к нему свое отношение ${ }^{18}$. В контексте нашего изложения вопроса знаменателен следующий отрывок из его сохранившихся фрагментов к “Курсу общей лингвистики”:

On se rend compte que c'est le détail ultime des phénomènes qui est aussi leur raison ultime, et qu'ainsi l'extrême spécialisation peut seul servir efficacement l'extrême généralisation. [. . . ] les noms qu'on aurait à citer dans ce sens seraient des noms de romanistes comme M. Gaston Paris [. . .], des noms de germanistes comme M. Hermann Paul, des noms de l'école russe s'occupant spécialement du russe et du slave, comme M. N. [sic! (Jan)-Niecisław? - И. П.] Baudouin de Courtenay, M. Kruszewski (= Мы отдаем себе отчет в том, что именно в предельно подробной детализации явлений заключается их конечный смысл, и именно поэтому лишь с помощью предельной специализации можно добиться предельных обобщений. [. . .] следовало бы

16 С тем чтобы оправдать высказанный мной в сноске 10 упрек в сторону классического перевода Сухотина, здесь будет уместным заметить, что, например, начало данного предложения он перевел как “только в 70-х годах XIX в.” [дЕ Соссюр 2006: 31]. Тем самым у читателя автоматически возникают ассоциации с учением младограмматиков 1870-х гг. Однако это лишь отчасти правильно. Несмотря на то, что в дальнейшем изложении де Соссюр действительно называет их имена, здесь, скорее, подразумевается то, что стояло у истоков младограмматизма, - около 1870 г. В общем контексте описанной ситуации данная датировка, на наш взгляд, заслуживает особого внимания и дальнейшего изучения.

17 См. комментарии Де Maypo: o “Leipzig et le «Mémoire»” в издании [DE SAUSSURE 1972: 325-334] и об отношении к Бодуэну де Куртенэ [IBID.: 338-340].

18 Особенно показательно в этой связи мнение Э. Косериу: он критикует современных лингвистов за то, что они очень часто не знают истории собственной науки и оказываются не в состоянии установить исторические связи, по инерции приписывая первенство введения той или иной категории ученым, которые ее не вводили, и вычеркивая тем самым из научной памяти имена людей, заслуги которых ни в коем случае не должны быть сбрасываемы со счетов: “Ainsi, par exemple, on attribue presque toujours à Saussure les distinctions entre langue et parole, entre signifiant et signifié, entre synchronie et diachronie, toutes distinctions que Saussure a retrouvées dans la tradition, qu'il a, sans doute, reformulée et auxquelles il a donné en partie une interprétation nouvelle, dans le cadre d'un système cohérent, mais qu'il n'a pas été le premier à formuler (= Так, например, различения между языком и речью, означающим и означаемым, синхронией и диахронией практически всегда приписываются де Соссюру, - различения, которые де Соссюр позаимствовал из традиции, которым он, возможно, дал новую формулировку и частично новую интерпретацию в рамках некой цельной системы, которые он, однако, ни в коем случае не сформулировал первым)" [COSERIU 1967/1972: 74]. 
упомянуть в этой связи имена таких романистов, как г-н Гастон Парис, [. . .] таких германистов, как г-н Герман Пауль, имена представителей русской школы, которые занимаются прежде всего русским и славянскими языками, таких как г-н Н. [(Ян)-Нечислав?] Бодуэн де Куртенэ, г-н Крушевский) [DE SAUSSURE 2002: 147].

Историко-языковые исследования в области славистики составляли тогда неотъемлемую часть общего контекста европейской лингвистической науки: с одной стороны, они учитывали ее опыт, с другой - задавали ей новые импульсы ${ }^{19}$.

На славянской почве концепция 'внутренней и внешней истории языка’, эксплицитно выраженная Бодуэном де Куртенэ в 1870 г., была реализована на практике в опубликованном в 1892 г. труде А. С. Будиловича “Общеславянский язык в ряду других общих языков древней и новой Европы” - одном из первых сравнительных исследований внешней истории европейских языков, фактически забытом сегодня в славистике и совершенно неизвестном в западноевропейской филологии [Будилович 1892] ${ }^{20}$. Будилович “предприня[лъ]” для своего исследования “пођздку въ Вьну, Парижъ и Берлинъ”, чтобы просмотреть “какъ книги, такъ и журнальныя статьи [. . .] по исторіи языковъ западной Европы” [IBID., 1: 2]. Тем самым ему удалось собрать и обобщить актуальное тогда научное знание и применить его к славянской традиции.

Уже после беглого знакомства с содержанием обоих томов его труда становится очевидным, что план, по которому двигался ученый (1892 г.), во многом предваряет пункты цитированной выше программы Гастона Париса (1897 г.): Будилович начинает с описания условий возникновения языка, затем обращается к вопросу о появлении и распространении письменности, переходит к процессу расширения географического ареала пользования языком, рассматривает разницу между литературным и общеупотребительным языком, анализирует работы грамматистов и останавливается на аспекте культивирования языка. Развитие “внутренних особенностей” письменных языков Будилович ставит в зависимость от “внешних судеб” этих языков. Под “внешними судьбами”21 он подразумевает развернутый анализ внеязыковых факторов,

19 См., например, ряд работ Г. Кайперта, посвященных влиянию немецкой научной традиции на славянскую и в том числе русскую филологию в первой половине XIX в. [KEIPERT 1996; 2004A; 2004в; 2006A; 2006в], и его замечание: “Сегодня, когда в славистике собственные интересы каждой национальной филологии все больше выступают на передний план, не следует забывать о том, что славянское языкознание как наука возникло в XIX в. благодаря совместной работе ученых различных европейских стран" [КEIPERT 2006в: 317].

20 О месте этого труда в научной традиции см. в [KEIPERT 1999A; 2003: 472].

21 Выражение “судьбы языка” употребляет также Бодуэн де Куртенэ: объясняя разницу между внутренней и внешней историей языка, он пишет, например, что 
таких как этнологический, географический, государственный, общественный, церковный и литературный.

Предваряя Париса, Будилович, тем не менее, не был оригинален. Ту же самую схему можно, например, найти в исследовании Адольфа Социна о немецком литературном языке и диалектах (“Schriftsprache und Dialekte im Deutschen nach Zeugnissen alter und neuer Zeit") [Socin 1888] и в издаваемых Густавом Грёбером “Очерках по романской филологии" (“Grundriss der romanischen Philologie”), первый том которых, посвященный историко-языковым проблемам, вышел, так же как и исследование Социна, в 1888 г. (см. [GRÖBER 1888A] и особенно [GRÖBER 1888в; 1888C]). На обе книги Будилович не однажды ссылается в упомянутом выше труде (см., например, [Будилович 1892, 1: гл. 2-5, 7 и др.]). Предложенная же им типология “литературных языков”, которую он развивает также в других своих работах (см., например, [IBID. 1887; 1893]), опирается прежде всего на немецкую филологическую традицию, в том числе на работы Г. Остго$\phi а$, В. Майера и Э. Царнке 22 , на которые также регулярно делаются ссылки.

Понятие ‘литературный язык’ у Будиловича равнозначно понятию 'письменный язык', т. е. язык письменности, язык всех видов документов, а в том числе и язык литературных произведений, что в принципе характерно для языкознания втор. пол. XIX - нач. XX в. Именно в таком значении употребляли это выражение все перечисленные выше авторы $^{23}$. При этом исследование языка различного рода документов и языка литературных произведений, как уже было показано выше, в 1870-е - 1890-е гг. осознавалось как один из обязательных пунктов “программы” 'внешней истории языка'.

В 1889 г. со славянской стороны над этим пунктом целенаправленно работал А. И. Соболевский. Опираясь главным образом на “Христоматию” Ф. И. Буслаева [1861], он систематически описал языковые

\footnotetext{
первая “не заботится о судьбах языка” [BAUDOUIN DE COURTENAY 1974-1990, 4: 56, прим. 34].

22 См. [Osthoff 1883; MeYer 1888: 377-382; ZARncKe 1890: 377-382].

${ }^{23}$ Ср. также [CARTER 1998] и [BAUM 1987: 16-18]. Р. Баум находит следы употребления термина литературный/письменный язык еще у Руссо, который рассуждает о том, какую пользу приносят языку хорошо написанные книги и хорошо пишущие авторы ("les livres bien écrits", "les Ecrits des bons Auteurs"), ведь язык совершенствуется прежде всего за счет письменности и в гораздо меньшей степени за счет устной речи ("par l'écriture et si peu par la parole"). Показательна дефиниция литературного языка, данная де Соссюром. Она также выдержана в традициях XIX в.: “Par 'langue littéraire’ nous entendons non seulement la langue de la littérature, mais, dans un sens plus général, tout espèce de langue cultivée, officielle ou non, au service de la communauté tout entière (= Под ‘литературным языком’ мы понимаем не только язык литературы, но, в более общем смысле, всякий язык, будь он государственный или нет, который культивирован и находится на службе у целого общества)" [DE SAUSSURE 1972: 267].
} 
особенности опубликованных в ней восточнославянских памятников письменности XI-XVIII вв. ${ }^{24}$ Определение Соболевским понятия 'литературный язык’ вписывается в современный исследователю общеевропейский научный контекст. Он исходит из уже знакомого нам по приведенным выше цитатам тезиса о том, что “литературный язык народа и просто язык народа часто не совпадают друг с другом” [СоьолЕвский 1980: 21-22]. То, что он понимает под литературным языком, очень четко укладывается в следующую схему:

Ср. в тексте:

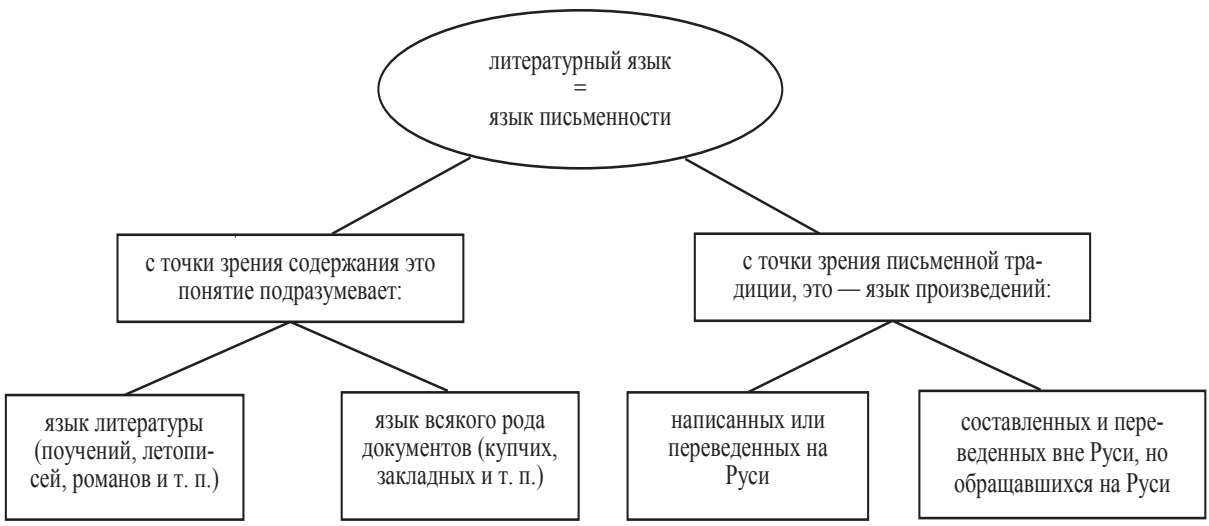

[П]од литературным языком мы будем разуметь не только тот язык, которым писались и пишутся произведения литературы в обычном употреблении этого слова, но вообще язык письменности. Таким образом, мы будем говорить не только о языке поучений, летописей, романов, но и о языке всякого рода документов вроде купчих, закладных и т. п., не только о языке произведений, написанных или переведенных в России, но и о языке произведений, составленных и переведенных вне России, но обращавшихся в России, вроде Евангелия, Апостола, богослужебных книг, творений отцов церкви [там же: 22].

Понимая термин литературный язык как 'язык письменности', или 'письменный язык', Соболевский делает вывод о том, что “русских литературных языков” было несколько: “. . . мы имели и отчасти имеем несколько литературных языков” [тАм ЖЕ]. В качестве примеров, иллюстрирующих данный тезис, во вступительной части своей работы он называет:

а) церковнославянский язык "среднерусского извода, который с течением времени сделался общерусским литературным языком и после многих исправлений и дополнений превратился в ныне существующий литературный язык",

${ }^{24}$ На то, что буслаевское издание послужило источником для Соболевского, указывает А. А. АлЕКСЕЕв [1980А: 6]. 
б) “народный живой русский язык”, зафиксированный уже в древнейших памятниках, а потому литературный,

в) церковнославянский язык Новгорода XIV в.,

г) церковнославянский язык Западной Руси XVII в.,

д) латинский язык в Галиции XV в.,

е) польский язык в Юго-Западной Руси XVI в. [тАм жЕ: 22-23].

В дальнейшем ходе исследования Соболевский расширяет этот список ровно вдвое, доведя его до двенадцати пунктов.

Совершенно очевидно, что фразу Соболевского “мы имеем в виду говорить о всех русских литературных языках” [ТАм жЕ: 22; курсив наш. - И. П.], какой бы она ни казалась понятной, современный исследователь обязан п е р е в о д и ь на современный научный язык: речь не идет о выработанном в пражском лингвистическом кружке социолингвистическом/социокультурном понятии 'литературный язык'. Автор рассматривает здесь вопрос о том, какие языки употреблялись в качестве письменных на территории Древней Руси, т. е. на восточнославянской территории.

Характерной особенностью научного дискурса второй половины XIX в. было употребление термина литературный язык во множественном числе, что соответствовало пониманию его как 'письменный язык’. Филолог-классик Эдуард Царнке, например, называет свой труд “Возникновение греческих литературных языков” (“Die Entstehung der griechischen Literatursprachen”) [ZARNCKE 1890]. В “Очерках” Грёбера регулярно встречается выражение романские литературные языки или литературные языки романских стран, при этом в число этих романских литературных языков входят наряду с итальянским, испанским, французским и др. собственно романскими языками также языки арабский, немецкий и греческий [GRÖBER 1888A: 281-822]. Именно по этой модели используется термин русский литературный язык / русские литературные языки у Соболевского ${ }^{25}$.

Соболевский не называл своего курса "Историей русского литературного языка”. Это название, как замечает А. А. Алексеев, было подписано позже, вероятно, Л. Н. Туницким, в чьем архиве хранилась рукопись Соболевского [АЛЕкСеЕв 1980б: 159]. Конечно, не следует исключать того, что авторское название могло бы быть именно таким, но в этом случае цель автора, которая скрывалась бы за этим названием,

25 Отдельного исследования заслуживает употребление в научном дискурсе того времени термина общий язык. Ему посвящена, например, отдельная глава “Gemeinsprache” в “Принципах истории языка” Г. Пауля [PAUL 1920: 404-422], акцент в ней делается на том, что “общими” могут быть как литературные, так и разговорные, общеупотребительные языки. Пауль называет “общий язык” нормой. А норма может быть как письменной, так и устной. См., кроме того, примеры в [BAUм 1987: 250]. 
была бы принципиально иной по сравнению со смыслом, который сегодня следовало бы по умолчанию давать термину литературный язык. Курс лекций Соболевского и, например, “История русского литературного языка” Успенского [УспЕнский 2002] имеют два разных объекта исследования и представляют собой два разных по содержанию курса: первый посвящен письменным языкам восточных славян, второй становлению нормы русского литературного, т. е. стандартного, языка. Мы неизбежно допускаем эпистемологический сдвиг, когда: 1) из курса лекций делаем научный трактат (случай, аналогичный с курсом лекций де Соссюра), 2) накладываем категории современного научного мышления на работу исследователя второй половины XIX в., не придавая значения научному контексту, в котором возникла эта работа, и не задаваясь вопросом, в каком, собственно, значении употребляется в ней тот или иной термин.

Мы должны исходить из того, что научная и преподавательская деятельность Соболевского отражала основные тенденции общеевропейской историко-языковой науки второй половины XIX в. Причем его немалая заслуга состоит в том, что он попытался вписать в этот контекст русистику. Обратим внимание на читаемые им университетские курсы: они покрывают собой разные аспекты одного и того же предмета. С одной стороны, это 'внутренняя история языка':

историческая грамматика, фонетика церковнославянского языка, русский исторический синтаксис все это дисциплины, получившие особенное развитие в лингвистике того времени

С другой стороны - 'внешняя история языка', которую составляют:

диалектология:

палеография: ср. выше у Бодуэна де Куртене, фон дер Габеленца, Париса, де Соссюра требование к изучению географического распространения и разветвления языка; у Пауля диалектология является одним из принципов истории языка [PAUL 1920: 37-48]; эта же идея заявлена в первом томе изданных Грёбером очерков, при этом том сопровождается диалектологическими картами романских языков [GRÖBER 1888A]; на 1880-е гг. приходится деятельность Адольфа Социна, который видит в диалектологии неотъемлемый компонент 'внешней истории языка' [SocIN 1888]; о развитии диалектологии во второй половине XIX в. см. в [KNOоP 1982] и [SONDEREGGER 1983];

ср. утверждение Бодуэна де Куртенэ: “палеография является необходимой помощницей языковедения” [BAUDOUIN DE COURTENAY 1974-1990, 4: 50, прим. 27]; Соболевский в данном случае закрывает лакуну в славистических штудиях: в западноевропейской науке к тому времени возникли целые школы палеографических исследований, а в университетах читались обязательные курсы 
переводная литература:

судьбы церковнославянского языка: по палеографии (см. об этом в [TRAUBE 1909: 60-80]); палеография как обязательная часть языковой истории представлена B. Шумом [SCHUм 1888]; интерес к палеографии связан также с проблемой языка и письма в историческом аспекте [PAUL 1920: 373-389; VON DER GABELENTZ 1972: 127-135]);

литературное наследие, переводное и оригинальное, находилось в то время в центре пристального внимания германистов, романистов, филологов-классиков, причем именно как часть языковой истории; показательно, что, например, Г. Грёбер подчеркивал неуместность терминологического выражения история романской литературы и предлагал заменить его на выражение история литературной продукиии в романских странах ("Geschichte der litterarischen Leistungen in romanischer Sprache/ Schriftum der Romanen”), потому что в этом случае будут также охвачены сочинения на латинском языке, переводная письменность и различного рода документы [GRÖBER 1888D: 152]; заслуга Соболевского, безусловно, состоит в том, что он сделал акцент на переводном характере средневековой славянской письменности; обращение историка языка к литературному наследию было совершенно естественным явлением в филологии того времени; в этом отношении интересный материал для целого исследования в области истории науки может дать сравнение двух научных фигур второй половины XIX в. - россиянина Соболевского и француза Париса, историка литературы, который одновременно пишет историческую грамматику французского языка;

исследование языковых судеб - требование, которое как имплицитно, так и эксплицитно выражено во всех приведенных выше цитатах; этот вопрос затрагивается Бодуэном де Куртенэ (см. выше сноску 21), обстоятельно разбирается Будиловичем (см. выше); сам Соболевский в другой своей работе ссылался на труд Билярского с подобным названием [Соболевский 1962: 286; Билярский $1847 / 48]$; в очерках Грёбера подробно рассматривается вопрос о судьбах языков в романских странах [GRÖBER 1888A: 415822]; Майер в главе “Письменный язык” (“Schriftsprache”) описывает судьбу латинского языка по схеме, в общих чертах использованной впоследствии Будиловичем и Соболевским: латынь как язык писателей $\rightarrow$ язык церкви $\rightarrow$ язык государства [MEYER 1888: 377-382] (у Соболевского, разумеется, иная последовательность: история русского литературного языка как языка церкви (= церковнославянский) $\rightarrow$ языка государства $\rightarrow$ языка писателей);

русская этнография: ср. выше высказывания Бодуэна де Куртэне, фон дер Габеленца и де Соссюра о связи языкознания и этнографии; Грёбер причисляет этнографию квспомогательным дисциплинам языкознания, без которых не обходится история языка [GRÖBER 1888D: 152];

заимствованные слова: cp. выше у Бодуэна де Куртенэ требование изучать влияние иностранных языков; у Пауля исследование заимствований пред- 
ставлено как один из принципов истории языка [PAUL 1920: 390408]; у фон дер Габеленца этот аспект специально оговаривается в рамках 'внешней истории языка' как метод для установления языкового родства [VON DER GABELENTZ 1972: 154-156].

А. А. Алексеев, перечислив все эти прочитанные Соболевским курсы, констатирует:

... в ряду этих предметов естественно помещается история литературного языка, рассматриваемая им как история функционирования определенных языковых форм в составе памятников письменности, как “внешняя” история языка [АлЕкCEEB 1980a: 5-6].

Это последнее уточнение - “как «внешняя» история языка” - с точки зрения истории науки имеет принципиальное значение, потому что именно за ним кроется смена научных парадигм, которую современные исследователи, как правило, не принимают во внимание, ставя Соболевского в один ряд с собой и не учитывая того, что история литературного языка для ученого XIX в. - это всего лишь один из аспектов 'внешней истории языка'.

Одновременно с Соболевским этот аспект, кроме Будиловича, разрабатывают А. Н. Пыпин и Е. Ф. Карский. Показательно то, что Пыпин посвятил истории литературного языка отдельную главу - “XVIII век. Наука и народность: язык народный и литературный” - в своем труде по русской этнографии [Пыпин 1890: 161-172] 26 . Этнография также составляет специфическую область интересов Е. Ф. Карского [1962] (впервые - 1893). Кроме того, как и Соболевский, Пыпин и Карский занимаются диалектологией, палеографией и историей литературы, посвящая также отдельные публикации вопросам 'внутренней истории языка', в частности исторической фонетике и исторической грамматике. В начале же XX в. все эти аспекты: этнография, диалектология, палеография, история литературы, внешние судьбы языка, историческая грамматика и фонетика - станут программными для проекта “Славянской энциклопедии”, в одном из томов которой будет опубликован очерк Е. Ф. Будде об истории русского литературного языка (см. [БуддЕ 1908]; очерк предваряет “программа”).

Для всех этих авторов литературный язык представляет интерес прежде всего как язык письменности, т. е. письменный язык. Исследование его истории является частью исследования истории духовной культуры, истории народа, истории государства. Все эти авторы мыслят в

26 Отдельного исследования заслуживают текстуальные совпадения у Пыпина, Карского и Соболевского. Совершенно очевидно, что все три исследователя знали работы друг друга или же, как минимум, имели возможность обсуждать друг с другом данный вопрос. 
категориях дихотомии 'внутренняя и внешняя история языка'. История русского литературного языка в гуманитарной науке кон. XIX - нач. $\mathrm{XX}$ вв. располагается в одном ряду с историей русской словесности/ литературы, этнографией, диалектологией, палеографией и т. д. Все это - составные части 'внешней истории языка', которая и стоит в центре научного внимания и подразумевает непосредственное исследование политических, экономических, социальных, религиозных и культурных условий жизни языка.

Однако отличительной чертой дальнейшей рецепции концепта 'внешняя история языка' в славянской филологии, и особенно в русистике, станет то, что он будет вытеснен понятием 'история литературного языка', при этом область интересов 'внешней истории языка' окажется значительно суженной. Поскольку это вытеснение сыграет важную роль в представлении об истории языка, равно как и в формировании терминологического аппарата советской и постсоветской славистики, мы остановимся на нем подробнее.

\section{3. 'Внешняя история языка' vs. 'история литературного языка'}

Думается, можно назвать, как минимум, три причины смены парадигм лингвистического мышления в России - смены, манифестирующей себя через конкуренцию терминов 'внешняя история языка' и 'история литературного языка'. Первая причина - это культивирование феномена 'литературный язык’ учеными Пражского лингвистического кружка; вторая - фактически официальный запрет на употребление дихотомии 'внутренняя и внешняя история языка' в советской науке; третья - отсутствие навыка осмыслять научную традицию в ее исторических взаимосвязях.

Пражский лингвистический кружок, как известно, сменил перспективу языковедческих исследований, развивая в рамках функциональной лингвистики основной методологический принцип структурализма о примате синхронии над диахронией. Если для младограмматиков интерес представляли прежде всего закономерности исторических изменений в языке и реконструкция праязыка, пражские лингвисты объявили исходным пунктом своих интересов современный национальный язык, важнейшей формой функционирования которого в рамках разрабатываемой ими теории языковой культуры оказался литературный, или стандартный, язык (чеш. spisovnýjazyk). Они видели в нем идеальное воплощение системы, что, с точки зрения структурализма, и должно было представлять первоочередной интерес для лингвистики. То, что у младограмматиков и их современников составляло главный предмет 
исследования, в Пражской школе стало играть второстепенную роль, потому что не разрешало главной задачи новой лингвистической программы, сосредоточенной вокруг вопроса, чем норма литературного языка отличается от нормы народного языка. Эта установка заявлена, например, в тезисе $3 \mathrm{~b}$, который, по сути, является реакцией на концепт 'внешняя история языка' и одновременно отказом от него как от не представляющей самостоятельного интереса области исследования:

Dans la formation des langues littéraires, les conditions politiques, sociales, économiques et religieuses ne sont que des facteurs extérieurs; ils aident à expliquer pourquoi telle langue littéraire est sortie précisément de tel dialecte déterminé, pourquoi elle s'est constituée et fixée à telle époque, mais ces conditions n'expliquent pas pourquoi elle s'est distinguée et en quoi elle se distingue de la langue populaire (= При образовании литературных языков условия политические, социальные, экономические и религиозные суть лишь внешние факторы; они помогают объяснить, почему данный литературный язык развился именно из указанного диалекта, почему он образовался и закрепился в данную эпоху, но эти условия не объясняют, почему он выделился и в чем он отличается от народного языка) [THЀSES 1929: 15-16; курсив оригинала. - И. П.] $]^{27}$.

По мнению пражских лингвистов, диахрония бессистемна, синхрония же системна, поэтому и следует заниматься синхронным срезом литературного языка. Пражцами была разработана целая теория литературHых языков [JEDLIČKA 1982; HORÁLEK 1976: 34-39; VYKYPĚL 2013: 21-26, 39-44], которая, судя по количеству посвященных ей работ, превратилась в своего рода культ филологической науки ${ }^{28}$. Помимо собственно

27 В несколько иной формулировке этот тезис воспроизводится в монографии Б. Гавранека "Studie o spisovném jazyce (= Очерк о литературном (букв.: письменном!) языке)”, ср.: “. . . př́i vytváření spisovného jazyka jsou p o m ě r y politické, sociální, hospodářské, náboženské a kulturní jen v něj ším i či n i t e li; jen pomáhají vysvětlovat, proč se právě jisté nářečí stalo základem pro spisovný jazyk, proč se spisovný jazyk rozšriril na tom neb onom území, proč vznikl a ustálil se v té neb oné době, ale nevysvětlují, proč se odlišil a v čem se odlišuje spisovný jazyk od jazyka lidového (a hovorového) (= При образовании литературного (букв.: письменного!) языка у с л в и я п о л и т и че ск и е, социальные, экономические, религиозные и культурные суть лишь в нешн и е факт о ры; они только помогают объяснить, почему именно это наречие стало основой литературного (письменного) языка, почему литературный (письменный) язык распространился на той или иной территории, почему он возник и закрепился в то или иное время, но они не объясняют, почему выделился и в чем отличается литературный (письменный) язык от языка народного (разговорного))" [HAVRÁNEK 1963: 12; разрядка автора. - И. П.].

28 У истоков этой теории стояли труд А. С. БудиловичА [1892] об общеславянском языке и восходящее к нему и запрещенное в Советском Союзе сочинение Н. С. Трубецкого “К проблеме русского самопознания” (1927 г.), отдельная глава которого - “Общеславянский элемент в русской культуре” - была посвящена вопросам литературного языка [ТруБЕцкой 1995] (пример рецепции идей Будиловича и Трубецкого в Пражском лингвистическом кружке см. в [KEIPERT 1999в: 130-132]). 
научного стремления обнаружить новые исследовательские объекты и создать новую исследовательскую программу, за этим культом стояли еще и чисто прагматические цели. С одной стороны, исследователи тем самым напрямую обращались к изучению характерной для чешской языковой ситуации диглоссии spisovný jazyk vs. obecná čeština. С другой стороны, формирование пражской лингвистической теории национальных литературных языков было тесно связано с культурно-политической ситуацией в Чехословакии $30-\mathrm{x}$ гг. XX в., времени, на которое и приходится кульминационный пункт развития данной теории: лингвисты видели свое предназначение в том, чтобы подчеркнуть цену языка собственной культуры, тем самым защитив его от возможного вытеснения другими языками [SCHARNHORST/ISING 1976/1982, 1: 17] (см. в более широкой перспективе: [TомAN 1995; Vүкүре̌L 2013: 45-50]).

Понятие 'литературный язык’ получило в Пражской школе новое наполнение: это был более не язык литературных произведений в его историческом развитии, что представляло основной интерес для языковедов XIX - начала XX в., но самостоятельное социокультурное явление современной общественной жизни, которое обладает рядом свойственных только ему признаков. Наиболее лаконично эти признаки были сформулированы, как известно, А. В. Исаченко, подчеркнувшим также разницу между понятиями ‘литературный язык’ и ‘письменный язык’:

Литературный язык, в современном понимании этого термина, обладает следующими признаками: 1) он поливалентен, т. е. применим для обслуживания всех сфер национальной жизни; 2) он нормирован (в отношении орфографии и орфоэпии, грамматики и словаря); 3) он общеобязателен для всех членов данного национального коллектива и в связи с этим не допускает диалектных вариантов; 4) он стилистически дифференцирован. Ни один из употреблявшихся на территории славянских народов письменных языков не обладал, до появления современных национальных языков, всеми указанными признаками. Поэтому предпочитаем говорить о письменных языках в применении к донациональным типам графически запечатленной речи [ИсАчЕнко 1958: 42; курсив автора.- И. П.] ${ }^{29}$.

В представленных к первому Съезду славистов (1929 г.) Тезисах Пражского лингвистического кружка, написанных по-французски, употреблялся термин langue littéraire. В чешскоязычных статьях пражцев ему соответствовал термин spisovnýjazyk (ср. название книги [HAVRÁNEK 1963]), получивший новое осмысление в теории функциональной лингвистики, а именно - ‘стандартный язык’30. На русский язык выражение langue

${ }^{29}$ Сp. [KeIPERT 1982: 70; 1988: 314 = 1991: 87] и [Живов 1996: 14], но также [АлЕКСеЕв 2013: 9, 16].

30 О терминологических эквивалентах в разных языках см. [BRozović 1970: 14-16; JEDLIČKA 1978: 45-51; 1982: 40-41; BAUM 1987: 31-55]. 
littéraire было переведено уже готовым термином литературный язык, за употреблением которого, однако, стояла иная традиция, как было показано выше. Тем самым произошло наложение терминов друг на друга и слияние научных традиций, что мы и называем эпистемологическим сдвигом.

Попытаемся при помощи схемы обобщить пункты расхождения, свидетельствующие о смене научной парадигмы в историко-языковых штудия XX Х в. - смене, которая, на наш взгляд, одновременно является и одной из причин эпистемологического сдвига во всей последующей научной традиции. По принципу хиазма поменялись местами гипонимы и гиперонимы: гипоним младограмматиков 'литературный язык' в теории функциональной лингвистики (в ее русском переводе!) занял место гиперонима:

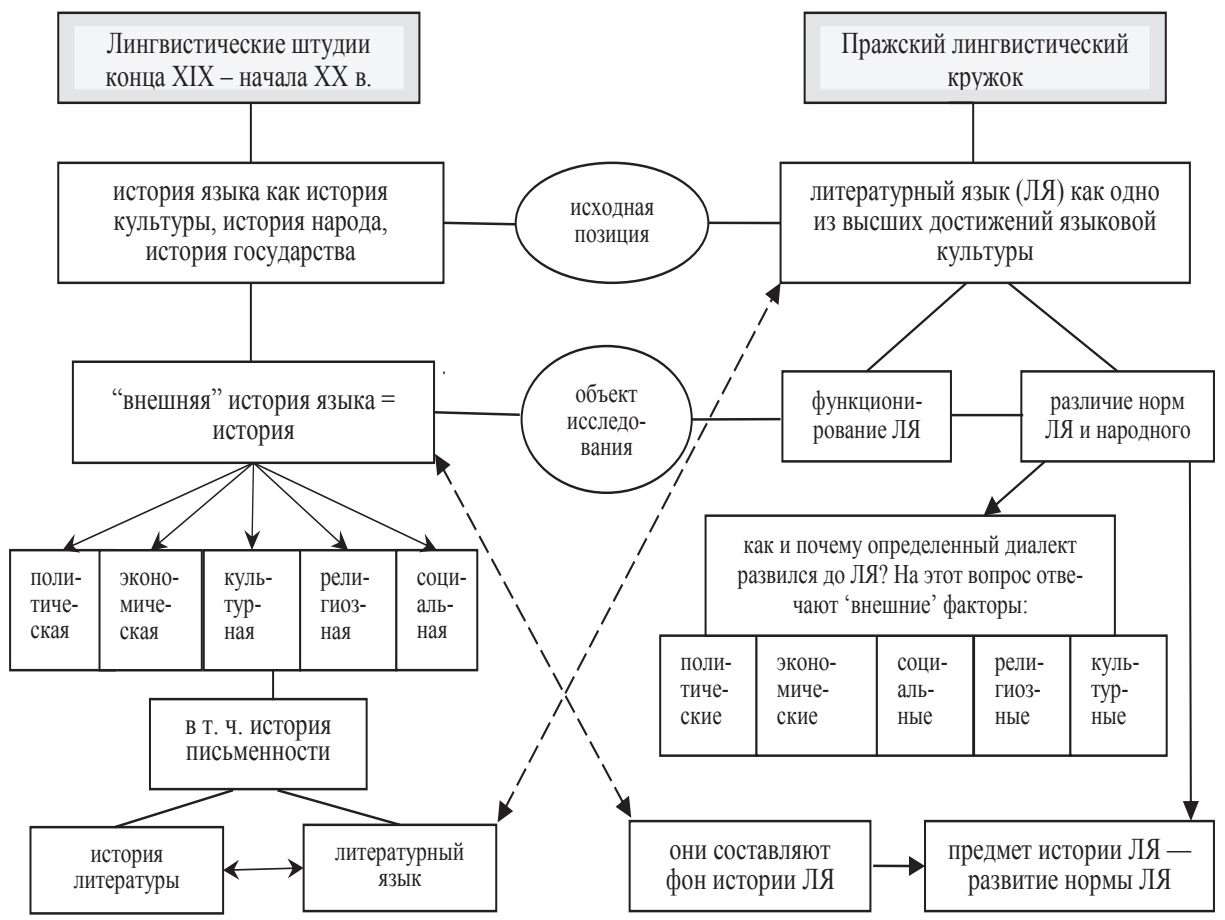

Однако такое наложение имеет место лишь на формальном уровне, потому что на уровне содержания мы реально располагаем омонимическими понятиями, каждое из которых имеет собственное значение:

литературный язык ${ }^{1}$

письменный язык, язык литературных произведений и документов (в понимании Соболевского и ученых конца XIX - начала XX в.); 
литературный язык²

стандартный язык, который в том числе может функционировать как язык литературных произведений (в понимании представителей Пражского лингвистического кружка).

Смешение этих понятий ведет, с одной стороны, к смешению предметов исследования: отдельный аспект 'внешней истории языка' оказывается самостоятельной дисциплиной - историей литературного языка; с другой стороны, к сужению области научных интересов: новая самостоятельная дисциплина ограничивается исследованием вопросов, которые были поставлены изначально в рамках одного лишь аспекта а именно, исследованием языка литературных произведений, т. е. сводится на уровень исторической стилистики [KEIPERT 1982: 67-68, 98; 1984; 1999с: 727; УСПЕНСКИй 2002: 7; АЛЕКСеЕв 2013: 5] - и отодвигает на задний план другие сферы исследования, которые в совокупности своей составляли некогда единое и обусловливающее друг друга целое.

Сами пражцы этого смешения не допускали. В истории литературного языка они хотели видеть историю развития его функций, но прежде всего историю развития его нормы, что соответствовало их представлениям о литературном языке как самостоятельном социокультурном явлении. Сейчас достаточно будет привести в качестве примера позицию Б. Гавранека в его монографическом очерке "Развитие чешского литературного языка” (“Vývoj spisovného jazyka českého”):

S hlediska vývojového je pak zvláště důležité to, že základním nositelem vývoje bývá v různých obdobích jazyk různého funkčního nebo sociálního zaměřění. Nešlo mi však v této stati o to, abych vylíčil obecně kulturní, sociální a politické pozadí rozvoje spisovné češtiny (t. zv. vnější dějiny), nýbrž šlo právě o její vnitřní vývoj jako jazyka spisovného, tedy o vývoj těch jazykových prostř̌edků, kterými spisovná čeština těmto funkčním a sociálním úkolům vyhovovala, o to, jak vznikala a měnila se její norma a jak se rozvíjelo její slovní a frazeologické bohatství (= С точки зрения эволюции в таком случае особенно важно то, что основным объектом развития в разные периоды времени является язык разной функциональной или социальной направленности. В данной работе моей целью не является описать общий культурный, социальный и политический фон развития чешского литературного языка (т. наз. внешнюю историю), но именно его внутреннюю эволюцию как языка литературного, а значит эволюцию тех языковых средств, с помощью которых литературный чешский язык исполнял ту самую [описанную выше. - И. П.] функциональную и социальную миссию, а также описать, как возникла и изменялась его норма и как развивалось его словарное и фразеологическое богатство) [HAvRÁNEK 1963: 1-2].

В западноевропейской филологической традиции - в германистике, романистике, англистике, классической филологии - термин литературный 
язык использовался и по-прежнему используется в своем изначальном значении, т. е. как 'письменный язык' [BUßмANN 2002: 412-413; GLÜCK 2005: 385; LEWANDOWSKI 1990, 2: 690-691; BAUM 1987: 35-53]. Кроме того, его исследование по-прежнему остается одним из аспектов 'внешней истории языка'. Когда же речь заходит о литературном языке в смысле Пражского лингвистического кружка, предпочитается термин стандартный язык [BUßмANN 2002: 648; GLÜсK 2005: 643; LEWANDOWSKI 1990, 23: 1096-1097; BESCH 1982; BAUM 1987: 50-55; см. также DANEŠ 1988; 2006]. В славистике же, несмотря на убедительную аргументацию Д. Брозовича [BRozović 1970: 14-16], второй термин не утвердился, что также стало одной из причин смешения понятий.

Однако далеко не последнюю роль в этом сыграл политический фактор: термин история литературного языка, употребление которого связывалось с отечественной научной традицией, внушал большее доверие, чем дихотомия 'внутренняя и внешняя история языка', на которой в первой трети XX в. стояла печать имени де Соссюра. В советской науке разделение лингвистики на ‘внутреннюю’ и ‘внешнюю’ было отвергнуто как “буржуазное”. Именно так охарактеризовал его Д. Н. Введенский в своем “вступительном слове” к опубликованному в 1933 г. русскому переводу “Курса общей лингвистики” де Соссюра ${ }^{31}$. В 1953 г. на русском языке вышел в свет очерк праславянской фонетики и морфологии чешского лингвиста Олдржиха Гуйера ${ }^{32}$. Книга начиналась с разделения истории языка на внутреннюю и внешнюю и с подробного описания областей исследования каждой из них [HUJER 1924: 1; ХуJEP 1935: 1]. Предисловие к русскому изданию было написано одним из основателей московской фонологической школы П. С. Кузнецовым. К упомянутой Гуйером в начале книги дихотомии П. С. Кузнецов отнесся критично:

Так, особенно теперь, после появления гениального труда И. В. Сталина по вопросам языкознания, в котором товарищ Сталин дает основополагающие указания о необходимости изучения истории языка в связи с историей народа, совершенно неприемлемо положение о внутренней и внешней истории языка как о чем-то взаимно обособленном. Такое понимание восходит в первую очередь к концепции так называемой французской “социологической” школы в языкознании. Между тем именно этот подход к явлениям истории языка мы обнаруживаем в некоторых разделах книги Гуйера [Кузнецов 2004: 5-6].

31 См. комментарии Де Мауро в [DE SAUSSURE 1972: 428] и [Введенский 1933: 12].

32 Как “Введение в историю чешского языка” (“Úvod do dějin jazyka českého”) эта книга впервые была опубликована в 1914 г. и затем переиздана в 1924 г. В 1935 г. с некоторыми изменениями и дополнениями она была издана на сербском языке как “Введение в историю славянских языков” (“Увод у историју словенских језика”). 
Идеологические коннотации, которые закрепились за лингвистическими терминами внутренняя и внешняя история языка, препятствовали объективной научной рефлексии связанных с ними проблем ${ }^{33}$.

Это третий из обозначенных нами выше факторов, повлиявших на смену парадигмы в отношении понятия 'внешняя история языка'. С одной стороны, новый этап филологической науки стремился обособиться от предыдущего, связывая себя с ним только формально, но не содержательно. С другой стороны, предшествующая научная традиция признавалась и трактовалась как начало науки, получившее продолжение в последующей традиции. Так, Н. И. Толстой писал, что

. . . такая дисциплина, как история русского литературного языка, почти не имела предыстории. Она началась как бы внезапно в конце тридцатых и серьезно заявила о себе в сороковых и пятидесятых годах и у нас, и в зарубежных славянских странах [Толстой 1992: 157].

В этих словах оценивается интерпретация литературного языка Пыпиным, сложившаяся в "подготовительный период" к науке о литературном языке. Заметим, что в одном отношении позиция автора оказывается близкой позиции "подготовительного" периода, согласно которой термин литературный язык употребляется в своем первом значении, т. е. как “письменный язык, язык литературных произведений”, но не как “стандартный язык”, хотя Н. И. Толстой и употребляет этот термин:

История русского литературного языка тесно связана с историей русской литературы. Правда, такая связь характерна прежде всего для истории языка художественной литературы, которую тот же В. В. Виноградов считал отдельной лингвистической дисциплиной, но и процессы развития книжного стандартного языка и развития книжности и словесности, как явления культурологические, при всей их специфичности, не намного отдалены друг от друга [ТАм жЕ: 157$158]$.

В современной лингвистике история и эпистемология языкознания как отрасли, подразумевающие систематический критический анализ лингвистических понятий в их историческом контексте, часто находятся в значительной изоляции от тех отраслей лингвистики, в которых осуществляются частные исследования. Современный историк языка в большинстве случаев не задается целью выяснить историю своей науки.

33 Ср. судьбу термина церковнославянский язык в [КеIPERT 2006с]: политически нежелательная лексема с религиозным значением в составе термина требовала замены, поэтому в советской научной традиции предпочитался термин старославянский язык, содержательно не соответствующий понятию “церковнославянский язык” и вызывающий неправильные ассоциации. 
С одной стороны, мы имеем ряд работ Г. Кайперта [КеIPERT 1982; 1984; 1985; 1988; 1991; 1999C], Б. А. УСПЕНСКОГО [1995/1997, 2002], В. М. ЖивовА [1996] и А. А. АЛЕкСЕЕВА [2013], которые в подходе к анализу истории литературного языка исходят из понятия “литературный язык’ в интерпретации Пражского лингвистического кружка, причем эта пражская линия проводится совершенно отчетливо. С другой стороны, многие русисты до сих пор трактуют историю литературного языка как историческую стилистику, ср.:

Поэтому вслед за Г. О. Винокуром можно сказать, что история русского литературного языка есть не что иное, как историческая стилистика русского языка. Описание исторически существовавших языковых стилей в их системных отношениях - первая задача истории русского литературного языка [КАмчАТнов 2008: 6] (со ссылкой на [Винокур 1959: 222]).

Мнение же, что в науке до сих пор не выработано четкого определения понятия ‘литературный язык', несмотря на то, что это определение было предельно четко сформулировано А. В. Исаченко (см. выше), стало общим местом в филологических работах (см., например, [ЖурАвлЕвы 2005]). Эта позиция получает свое окончательное закрепление на уровне системы преподавания. В учебном процессе высшей школы для курса “История русского литературного языка" до сих пор остаются авторитетными учебники В. В. Виноградова [1978; 1982] и А. И. Горшкова [1983; 1984], в которых литературный язык приравнивается к письменному языку, в смысле к языку литературы, и соответственно история литературного языка трактуется как смена языковых особенностей литературных произведений, другими словами, как историческая стилистика.

На самом же деле мы имеем дело со смешением, возникшим в результате наложения друг на друга двух омонимичных терминов и двух стоящих за ними традиций. Чтобы ликвидировать это досадное смешение, нужно прежде всего признать наличие первой, более ранней традиции в отечественном языкознании как полноценной и завершенной в себе. Отдав дань уважения Соболевскому как одному из крупнейших ученых своего времени и признав его реальный вклад в мировую лингвистику, нам, вероятно, следует прекратить попытки во что бы то ни стало вписать его линию в актуальный научный опыт. Работая же в рамках этого последнего, равно как и желая развивать предшествующую традицию, мы должны отдавать себе отчет в их эпистемологической конкуренции (если не автономности) по отношению друг к другу.

Возвращаясь к проблеме терминов внутренний и внешний, следует отметить, что дихотомия ‘внутренняя и внешняя история языка' в славянской филологии не получила такого широкого распространения, как, 
например, в романистике. Не будучи безызвестной славистам, она не стала традиционной исходной моделью историко-языковых штудий. Сегодня к ней прибегают преимущественно западноевропейские слависты [MOSER 2000: 129; BunčIĆ 2006: 21-26]. Отечественные же русисты, как правило, ограничиваются разделением 'историческая грамматика' vs. 'история литературного языка'. Первая соответствует 'внутренней истории языка' и является продолжением традиции исторической лингвистики XIX в. Вторая же должна была бы соответствовать 'внешней истории языка', которую она вытеснила. Однако закрепившийся термин не покрывает полностью вытесненного им понятия ${ }^{34}$. Это привело к сужению проблемного поля и методологической нечеткости и в конечном счете сказалось на общем состоянии современной палеославистики: мы располагаем печально малым числом работ, по глубине концепции и по охвату и осмыслению материала равных историко-языковым штудиям в области германистики, романистики или англистики.

\section{4. Альтернативная модель}

Предлагаемая ниже концепция базируется на соображении о том, что существует:

- с одной стороны, язык в его истории как некий объективный феномен, который развивается - или, дипломатичнее сказать, претерпевает изменения - во времени, т. е. существует история языка как объективная данность;

- с другой стороны, концепт истории языка, т. е. некие представления об историческом развитии языка, которые могут выражаться либо в априорном знании о том, что язык подвержен изменениям, либо в непосредственной фиксации этих изменений, их анализе и осмыслении в свете той или иной теории.

Обе эти стороны объединяются в рамках единой науки об историческом развитии языка, или истории языка. Мы будем понимать это терминологическое выражение как гипероним ${ }^{35}$, который предполагает даль-

${ }^{34}$ Исключение составляет “История русского литературного языка”

А. М. Камчатнова. С одной стороны, исследователь остается верным предшествующей традиции и трактует историю русского литературного языка как историю стилей (см. выше). С другой стороны, он придает большое значение внешним факторам, а именно культурно-историческому контексту той или иной эпохи: “. . . существенным компонентом, входящим в историю русского литературного языка, является анализ политических, религиозных, идеологических и историко-литературных элементов, образующих данный контеКст" [КАмчАТНОВ 2008: 3].

35 В поисках адекватного терминологического обозначения этой науки мы отдаем предпочтение именно термину история языка. В западноевропейской филологии 
нейшее членение на гипонимы, в частности на историческую диалектологию и на историю языка и его употребления ${ }^{36}$. Первая равнозначна 'внутренней', вторая - 'внешней истории языка'. Оскар Райхман осмысляет соотношение между историей языка как объектом и как концептом через призму двух уровней (букв.: плоскостей), на которых он размещает три понятия. Если попытаться визуализировать его рассуждения, например, в форме треугольника Фреге, можно получить следующую картину:

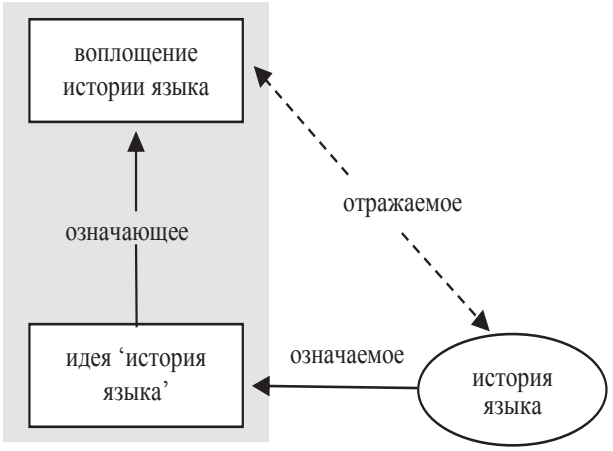

Es gibt Sprachgeschichte (Objektebene) [...]. Es gibt die Idee von Sprachgeschichte (erste Metaebene) [. . .]. Es gibt die Verwirklichung der Sprachgeschichte (ebenfalls erste Metaebene) ... (= Существует история языка (уровень объекта) [...]. Существует идея об истории языка (первый метауровень) [. . .]. Существует воплощение истории языка (также первый метауровень) . . .) [REICHMANN 1998: 1].

Петер фон Поленц передает то же самое соотношении иными словами. Первую часть введения к своей истории немецкого языка он называет

обобщающего термина, несмотря на ряд попыток сформировать единое понятие о соответствующем феномене, на сегодняшний день не существует (см. об этой проблеме в [MATTHEIER 1998: 824]). В качестве такового часто употребляются термины historiolinguistica (Historiolinguistik, historical linguistics) (см., например, [BoLten 1998: 124-127]) или историография языка (Sprachgeschichtsschreibung) (см. [ReichmanN 1998; von Polenz 1998], см. также выше, раздел 1). Однако вариант historiolinguistica не может быть выбран в качестве гиперонима, потому что он созвучен с термином историческая лингвистика, которым, как уже упоминалось выше (раздел 1), принято обозначать историческую грамматику и фонетику или историческую диалектологию. Вариант же историография языка неудобен потому, что он, скорее, будет иметь значение 'история науки о языке' (см. новейшую книгу [VYкYре̌L 2013: 7]). Еще один возможный вариант, термин диахронное языкознание, не отражает сути предмета (см. о проблемах, связанных с его употреблением и интерпретацией, в [JёGER 1998]).

${ }^{36}$ Обозначение история языка и его употребления мы заимствуем у Джофри Хоррокса (ср. название его книги "Greek: A History of the Language and its Speakers” [НоRRoскS 1997]). Вслед за Хорроксом тот же самый терминологический оборот в название своей книги помещает Ян Пресс (ср.: “A History of the Russian Language and its Speakers" [PRESS 2007: IX]), несмотря на то что, как замечает Г. Кайперт, содержание книги не соответствует тем ожиданиям, которые вызывает ее название [KEIPERT 2008: 203]. Адаптируя данное терминологическое обозначение к русскому языку, следует отказаться от перевода слова speakers как носители: речь не идет об истории носителей языка (ср. значение, которое придает слову speakers Пресс [PRESS 2007: IX]). Современным требованиям социопрагматического подхода к истории языка соответствует, на наш взгляд, именно выражение употребление языка. 
"Die Veränderbarkeit von Sprache und wie man darüber denkt (= Возможность изменять язык и что́ об этом думают)” [VON PoLENZ 1991-1994, 1: 2]. Историю языка сегодня принято представлять в категориях исторической социолингвистики и лингвопрагматики, которые и являются современной реализацией, или воплощением, идеи 'история языка'. C учетом наработанного в рамках этих направлений опыта создаются теории языковых изменений и модели описания языковой истории [MILROY 1992; LABOV 1994; 2001; Keller 2003; AitChison 2013].

Развитие социолингвистики в XX в. стало закономерным и предсказанным результатом дальнейшего развития науки о языке. Возникновение тезиса о социальной природе языка ни в коем случае не следует сводить к опубликованному в 1916 г. "Курсу общей лингвистики” де Соссюра. Уже в конце XIX в. он проходит красной нитью, например, у Бодуэна де Куртенэ ${ }^{37}$. В автобиографических заметках, частично опубликованных в “Критико-биографическом словаре русских писателей и ученых” С. А. Венгерова, описывая свои лингвистические установки, Бодуэн утверждал:

Такъ какъ языкъ возможенъ только въ человъческомъ обществъ, то кромъ психической стороны мы должны отмъчать въ немъ всегда сторону соціальную. Основаніемъ языковьдънія должна служить нетолько индивидуальная психологія, но и соціологія (до сихъ поръ, къ сожальнію, не на столько еще разработанная, чтобы можно было пользоваться ея готовыми выводами) [ВенгЕPOв 1897: 33] (см. также [BRANG/ZüLlig 1981: 2(19)]).

В очерке “Языкознание, или лингвистика” (“Językoznawstwo czyli lingwistyka”), опубликованном в сокращенном виде в 1901-м, полностью же в 1904 г., перспективы развития языковедческой науки в XX в. Бодуэн де Куртенэ видел в ее связи с другими дисциплинами и в том числе с социологией, при этом он предлагал объединять лингвистические кафедры в университетах не с филологическими, а с естественнонаучными и социологическими [BAUDOUIN DE COURTENAY 1974-1990, 1: 22, 23; BRANG/ZüLLIG 1981: 3 (№ 20)].

С социолингвистических позиций “думал” 38 о языке ученик Бодуэна Е. Д. Поливанов, один из крупнейших советских лингвистов 1920-х 1930-х гг., который также сделал шаг к исторической социолингвистике. В контексте нашей работы особенный интерес представляет его подход к истории языка и в этой связи его представления о том, каким должен быть ученый-лингвист:

\footnotetext{
37 Социолингвистическим взглядам Бодуэна де Куртенэ посвящено диссертационное исследование [BUDZIAK 1997].

38 См. выше в тексте (вверху этой страницы) цитату из [VoN PoLENZ 1991-1994, 1: 2].
} 
. . . мы нуждаемся в лингвистической историологии [сноска 2: Понимаем под историологией общее учение о механизме исторических процессов, и под лингвистической историологией, следовательно, - общее учение о механизме языковой эволюции]. [. . .] Языковое прошлое для нас - история культуры (наравне с памятниками материальной культуры и литературы), и в этом - “филологическом” - направлении наших интересов мы - историки ${ }^{39}$. Лингвист, таким образом, слагается: 1) из реального строителя (и эксперта в строительстве) современных языковых (и графических) культур [... . ; 2) из языкового политика, владеющего [. . .] прогнозом языкового будущего [. . .]; 3) из “общего лингвиста”, и в частности лингвистического историолога (здесь, в “общей лингвистике”, и лежит философское значение нашей науки); 4) из историка культуры и конкретных этнических культур [ПоливАнов 1960: 271-272].

Эти “думы”, направленные против марровского “нового учения о языке”, были высказаны Поливановым в статье “За марксистское языкознание” (1931 г.) и в предшествовавшем ей докладе в Коммунистической академии (1929 г.). Они стоили ученому жизни (арест по обвинению в шпионаже и расстрел в 1938 г.), потому что большинство лингвистов того времени “думали” о языке иначе.

Современная социопрагматическая теория языка исходит из тезиса о том, что центральным феноменом социальной жизни является потребность в коммуникации. Именно от потребности в коммуникации зависит “[der Grad] der Komplexität der Koordinierungsaufgaben, die durch Sprache gelöst werden müssen (= степень сложности координационных задач, которые должны быть разрешены посредством языка)" [MАттHEIER 1988: 1436]:

... jede Sprache [ist] eine Widerspiegelung des Kommunikationsbedarfs einer Gesellschaft. Wenn sich der Kommunikationsbedarf im Rahmen sozialer Veränderungen wandelt, dann wird die Sprache mit entsprechender Adaptionsverzögerung darauf reagieren und ihre Kommunikationskapazität verändern (= каждый язык является отражением коммуникативных потребностей общества. Когда в рамках социальных изменений меняются коммуникативные потребности, то язык будет реагировать на это, хотя и с некоторой задержкой, вызванной необходимостью адаптации, изменением своих коммуникативных возможностей) [IBID.].

Воплощая на практике идею 'история языка', историческая социо- и прагмалингвистика видит свою цель в том, чтобы установить и описать коммуникативные потребности общества на том или ином этапе его развития [IBID.].

На основании такого подхода к языку и к его истории картина о языке составляется через призму условий, в которых используется язык,

39 Ср. требование современного немецкого германиста П. фон Поленца включить историю языка в число исторических наук (см., например, [VON PoLENZ 2002: 15]); см. также выше в разделе 1. 
это значит, что любого рода высказывания воспринимаются как деятельность и интерпретируются в их взаимосвязи с социально-коммуникативным контекстом, который обусловил их употребление (ср. [СнЕRUBIM 1978: 6-7]).

Эволюцию языка, с точки зрения исторической социолингвистики и лингвопрагматики, предлагается рассматривать в том числе как эволюцию исторического языка [MATTHEIER 1988: 1432; GIOVANARDI 1999: 18-24; Косн 1988; 2002; DRÄXLER 1989: 18-28; BERUTto 2004], в том смысле, какой придавал этому термину Эуженио Косериу:

. . . eine historische Sprache [ist] ein Gefüge von historischen Traditionen des Sprechens, das eben als autonome "Sprache“ von seinen eigenen Sprechern und von den Sprechern anderer Sprachen anerkannt wird, was sich normalerweise dadurch zeigt, dass ein solches Gefüge durch ein adiectivum proprium bezeichnet wird, wie z. B. „,deutsche Sprache“, ,englische Sprache“, „französische Sprache“. Eine historische Sprache ist also eine Sprache, die schon als solche von anderen Sprachen historisch abgegrenzt ist, der dieser Status historisch zuerkannt wird [CosERIU 1988: 47-48] (ср. более подробно в [IDEM 2007: 24-25]).

Намеренно воздержимся от дословного перевода: у современного исследователя данное определение может вызвать ряд нареканий. Нам важно то, какое развитие получило введенное понятие в дальнейшей научной традиции ${ }^{40}$. Романист Йенс Людтке, парафразируя Косериу, предложил следующую дефиницию: “. . . eine historische Sprache [ist] das, was die eigenen Sprecher als eine solche anerkennen und selbst mit einem Namen belegen und dadurch abgrenzen (= исторический языкэто то, что говорящие-пищущие ${ }^{41}$ на нем признают как таковой, сами дают ему имя и тем самым отграничивают его)” [LÜDTKE 1999: 37]. Следует, кроме того, принять во внимание и уточнение самого Косериу к данному им определению: в задачи говорящих-пишущих входит лишь сообщить, что существует тот или иной язык, назвав его по имени, но не собственно отграничивать его от другого языка [CoseRIU 1988: 60].

В пределах одного исторического языка Косериу выделяет три вида различий, факт наличия которых является обязательным условием для того, чтобы обозначать тот или иной язык как исторический [IBID.: 49-50]. Это - различия диатопические (т. е. территориальные),

${ }^{40}$ Концепция Косериу не во всем безупречна, в ряде случаев она требует уточнений и дополнений (ср. [Звегинцев 1963]). Значительный интерес она представляет именно с точки зрения ее последующей рецепции в языкознании. Оценочная и содержательно некорректная интерпретация данной концепции в статье [НАрумов 2005], на наш взгляд, абсолютно неприемлема.

41 См. выше сноску 36, комментарий к переводу слова speakers: речь не идет только о носителях языка, но о всех его пользователях. 
диастратические (т. е. между социокультурными слоями) и диафазические (т. е. функциональные). Данные три вида различий заключают в себе три группы единств, которые, будучи закрепленными за конкретным языковым сообществом, определяют гомогенность языка. Это синтопические, синстратические и симфазические единства ${ }^{42}$. Первые Косериу называет диалектами, вторые - языковыми уровнями, третьи - стилями. Однако эти терминологические выражения не следует воспринимать буквально, потому что сам Косериу придавал им особенное значение. В категориях лингвистики языковых разновидностей, или языков-вариантов (Varietätenlinguistik), то, что Косериу называет диалектом, представляет собой национальный язык в его региональном воплощении (тосканский итальянский, швейцарский немецкий и т. д.); “языковой уровень” может подразумевать - с точки зрения теории диглосии - high variety, стандарт, но также разговорную речь, просторечие или же социолекты; “стиль” - это функциональный вариант или регистр [SPILLNER 1987: 274-275; SINNER 2014: 63-67] $]^{43}$.

\begin{tabular}{|c|l|l|l|}
\hline \multicolumn{4}{|c|}{ Исторический язык } \\
\hline \multicolumn{3}{|c|}{ согласно концепции Э. Косериу } & $\begin{array}{l}\text { в категориях лингвистики } \\
\text { языковых разновидностей }\end{array}$ \\
\hline различия & \multicolumn{1}{|c|}{ единства } & \multicolumn{1}{|c|}{ терминологические обозначения } \\
\hline диатопические & синтопические & диалект & регио- и диалекты \\
\hline диастратические & синстратические & $\begin{array}{l}\text { языковой } \\
\text { уровень }\end{array}$ & $\begin{array}{l}\text { в широком смысле: } \\
\text { high variety; } \\
\text { в узком смысле: социолекты }\end{array}$ \\
\hline диафазические & симфазические & $\begin{array}{l}\text { языковой } \\
\text { стиль }\end{array}$ & $\begin{array}{l}\text { функциональные языки- } \\
\text { варианты или регистры }\end{array}$ \\
\hline
\end{tabular}

Региолект может функционировать как high variety, a high variety может выступать как функциональный язык-вариант. Таким образом, региолект тоже может выступать как функциональный язык-вариант. Региолект и исторический язык, согласно Косериу, могут фактически

42 Термины диа-/синтопический и диа-/синстратический Косериу заимствует у норвежского романиста Л. Флюдаля, добавляя в этот ряд термин $\partial u a-/$ симфазический [FLYdAL 1952; COSERIU 1988: 50; SINNER 2014: 64; прим. 8].

43 Оправданность этой интерпретации станет очевидной, если принять во внимание другие работы Косериу, в частности, его переведенное на русский язык исследование “Синхрония, диахрония и история” [КосЕРиу 1963]. Кроме того, в пользу именно такой соотносимости предлагаемых Косериу выражений с терминами лингвистики языковых разновидностей свидетельствуют его примеры с судьбой латинского и коптского языков в приводимой далее цитате. 
заменять друг друга (см. [SINNER 2014: 51]). Региолект представляет собой ту форму исторического языка, которая расположена к нему ближе всего ("diejenige Form der historischen Sprache, die der historischen Sprache selbst am nächsten liegt”) [IвID.]. При этом региолект может развиться до нового исторического языка. В свою очередь, исторический язык может функционировать так же, как функционирует региолект. Это значит, что:

... eine historische Sprache kann in einer (anderen) Sprachgemeinschaft als Sprachniveau oder sogar als Sprachstil funktionieren, und sie kann ja auch wie ein Dialekt auf einen einzigen Sprachstil reduziert werden. So hat das Latein während einer langen Zeit in verschiedenen europäischen Sprachgemeinschaften als Sprachniveau bzw. als Sprachstil funktioniert, und das Koptische ist als Sprache der koptischen Kirche in Ägypten so gut wie auf einen einzigen Sprachstil reduziert worden (= исторический язык может функционировать в (другом) языковом сообществе как high variety resp. социолект или как функциональный язык-вариант, и точно так же, как и региолект, исторический язык может быть редуцирован до уровня одного-единственного функционального языка-варианта. Так, латинский язык в течение долгого времени функционировал в различных европейских языковых сообществах как high variety resp. социолект, а также как функциональный язык-вариант; коптский язык, будучи языком коптской церкви в Египте, был редуцирован лишь до уровня одного-единственного функционального языка-варианта) [IBID.].

В качестве примера мы предлагаем подойти с позиций данной концепции к церковнославянскому языку. Это не значит, что мы будем автоматически обозначать его как 'исторический язык’. Мы предлагаем лишь спроецировать введенное Косериу понятие на книжный язык сла' вян и рассмотреть его развитие в свете концепта 'исторический язык'.

Начнем с формальных признаков. Как во всяком историческом языке, в церковнославянском языке можно выделить три группы различий ${ }^{44}$, включающие в себя три группы единств:

- Во-первых, поскольку он долгое время не был кодифицирован грамматиками, а языковые сообщества, которые им пользовались, в качестве разговорных употребляли свои народные языки, церковнославянский язык был подвержен влиянию этих народных языков. В результате мы располагаем большим числом

44 Ср. статью Г. Кайперта, в которой безотносительно понятия “исторический язык” обобщенно представлены диахронические, диатопические и диафазические разновидности церковнославянского языка. Кроме того, отдельная глава в данной статье посвящается разновидностям церковнославянского языка, связанным с деятельностью отдельных личностей или групп resp. институций (“Personen- und gruppenbezogene Varietäten”), например, кирилло-мефодиевский церковнославянский, мелетианский церковнославянский (т. е. церковнославянский Мелетия Смотрицкого), постниконианский церковнославянский, синодальный церковнославянский и др. [КEIPERT 2014: 1237-1238]. Следует заметить, что эта классификация имеет самостоятельное значение и отражает специфические особенности исторического развития церковнославянского языка. Ее не следует путать с диастратической классификацией. 
региональных вариантов, которые в русскоязычной научной традиции принято называть редакциями или изводами (о термине см. [KEIPERT 2014: 1229-1230]). Это синтопические единства, составляющие диатопические различия внутри одного исторического языка (классифицируем их условно по географическому принципу, ср. [IBID.: 1231-1233]):

\section{ЦЕРКОВНОСЛАВЯНСКИЙ ЯЗЫК}

\begin{tabular}{|c|c|c|c|c|c|c|c|c|}
\hline \multicolumn{3}{|c|}{ восточнославянская редакция } & \multicolumn{4}{|c|}{ южнославянская редакция } & \multirow[b]{2}{*}{$\begin{array}{c}\text { западносла- } \\
\text { вянская } \\
\text { периферия }\end{array}$} & \multirow[b]{2}{*}{$\begin{array}{c}\text { славянское } \\
\text { книгописание } \\
\text { в неславян- } \\
\text { ских землях }\end{array}$} \\
\hline $\begin{array}{l}\text { в рутен- } \\
\text { ских } \\
\text { землях }\end{array}$ & $\begin{array}{c}\text { в велико- } \\
\text { русских } \\
\text { землях }\end{array}$ & $\cdots \cdots$ & $\begin{array}{l}\text { в хорват- } \\
\text { ских } \\
\text { землях }\end{array}$ & $\begin{array}{l}\text { в серб- } \\
\text { ских } \\
\text { землях }\end{array}$ & $\begin{array}{c}\text { в болгар- } \\
\text { ских } \\
\text { землях }\end{array}$ & $\cdots \cdots$ & & \\
\hline
\end{tabular}

- Bo-вторых, несмотря на то, что социокультурная история церковнославянского языка до сих пор не написана, нет оснований сомневаться в том, что уровень владения и пользования этим идиомом был очень различным, причем как среди самих книжников в самом широком смысле этого слова ${ }^{45}$, так и среди неграмотных слоев населения ${ }^{46}$. Потребность использовать церковнославянский язык и уровень языковой компетенции находились в прямой зависимости от социокультурного расслоения общества (диастратические различия, основанные на синстратических единствах). Мы предложим следующий - предварительный и требующий дальнейших специальных разработок - вариант схемы социокультурной лестницы, изображающей: 1) социокоммуникативную область использования церковнославянского языка, 2) действующих в ней акторов и 3) связанные с этой областью ожидания относительно языковой компетенции акторов. Эти ожидания весьма условны, они не означают, что уровень владения языком у всех перечисленных в той или иной области групп лиц действительно был соответствующим, однако этого уровня требовали коммуникативные задачи, разрешаемые в пределах данной области (см. схему на след. стр.). Показательно, что, например, на самой высокой ступени лестницы церковнославянский язык в древнерусский период мог заменяться на греческий, если митрополичью кафедру занимал грек. Специального исследования требуют знания церковнославянского языка в боярской среде (см. замечания А. А. АлЕксеЕвА [2013: 12] о роли бояр в истории русского языка).

- $\quad$ В-третьих, естественным образом предполагаются диафазические, или функциональные (ср. [KEIPERT 2014: 1234]) различия, объединяющие в себе симфазические единства. В качестве этих единств будут выступать жанры средневековой

45 См. определение понятия “книжник” у Д. М. БулАнинА [1987: 4].

46 Внимания заслуживает монографическое исследование А. А. МЕдынцевой [2000] о грамотности в Древней Руси: на основании данных эпиграфики здесь делается попытка представить уровень владения письмом в разных социальных слоях населения средневековой Руси. Социокультурный подход к изучению письменной культуры Древней Руси представлен в книге С. Франклина [FRANKLIN 2002]. 
использование

языка в

конфессио-

нальных целях

\begin{tabular}{|c|c|}
\hline $\begin{array}{l}\text { высшее духо- } \\
\text { венство и сред- } \\
\text { ний клир, в }\end{array}$ & $\begin{array}{l}\text { языка в церков- } \\
\text { но-государст- } \\
\text { венной сфере }\end{array}$ \\
\hline $\begin{array}{l}\text { чьи обязан- } \\
\text { ности входит }\end{array}$ & представители \\
\hline ведение служ- & княжеского \\
\hline бы и чтение & resp. царского \\
\hline проповедей; & двора; монахи- \\
\hline переводчики и & книжники, со- \\
\hline составители & стоящие при \\
\hline $\begin{array}{l}\text { сакральных } \\
\text { текстов }\end{array}$ & приказах \\
\hline
\end{tabular}

высшая степень владения языком, подразумевающая умение употреблять церковнославянский язык в устной и письменной речи и варьировать его употребление в зависимости от коммуникативной ситуации или коммуникативной формы (литургический текст vs. проповедь) употребле-

книг; обу-

чение чте-

и мирской

быт молитва во время службы

и в бытовых

ситуациях

прихожане, чья языковая компетенция ограничивается выученными наком, например по причине надлежности к другой конфессии

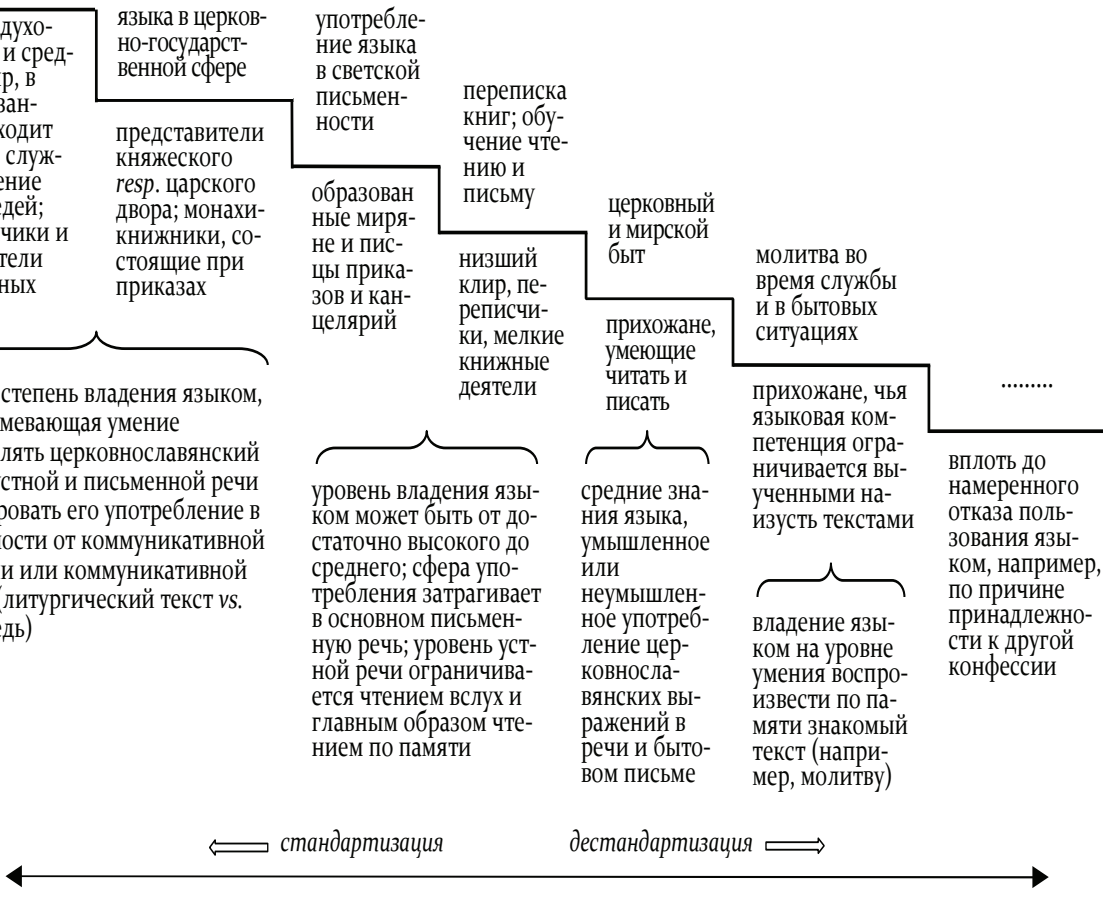

письменности: они задавали языковой канон, отделяя тем самым тексты одного жанра от другого. Жанровая иерархия в ее соотношении с дифференциацией языковых признаков и функциональным назначением того или иного вида текстов была разработана Н. И. Толстым для сербской церковнославянской книжности и представлена в форме пирамиды [ToLSTOJ 1982: 19]; к древнерусскому материалу ее предложили применить Г. Кайперт [КEIPERT 1988: 327-329 = 1991: 96; 2014: 1236] и А. А. АЛЕкСЕЕв [1989: 153$]^{47}$. Воспроизводить эту пирамиду еще раз будет излишним. Однако заметим, что модель Толстого, несмотря на высказанные А. А. Алексеевым [1989: 153] критические замечания, мы находим универсальной как для характеристики языковых особенностей и функционального назначения различных памятников письменности, так и для реконструкции языковой ситуации в тот или иной период развития восточнославянского, и в частности русского, языкового сообщества. С этой моделью соотносится предложенное В. М. Живовым деление книжного языка на регистры: стандартный и гибридный, - деление, которое также констатирует диафазические различия и симфазические единства внутри церковнославянского языка [Живов 1996: 31-41].

47 Кроме того, возможность переноса этой модели на средневековый русский языковой материал потенциально следует из статьи-рецензии Е. М. ВЕРЕщАГИНА [1989: 131-132] на книгу Н. И. Толстого. 
Таким образом, с формальной точки зрения церковнославянский язык обладает тем необходимым набором признаков, которые в совокупности своей позволяют осмыслять его как ‘исторический язык’. Однако это наши, сегодняшние, знания о церковнославянском языке. Это взгляд с о в р е м е н н о г о исследователя, рассматривающего книжный язык славян как язык, отличный от народных, а позднее национальных славянских языков, и тем самым обособляющего его как самостоятельный язык, как язык в современном смысле этого слова, несмотря на то что таковое обособление могло быть очень слабо выраженным или даже вообще не характерным для языкового сознания донационального периода.

Глоттоним церковнославянский является достоянием научной традиции XIX в., т. е. это научное обозначение языка ${ }^{48}$. Сами древние книжники называли язык тех текстов, которые мы сегодня называем церковнославянскими, либо согласно его функции - книжная речь (Зиновий Отенский), lingua sacra (Иван Ужевич), главный и книжный наш язык (Юрий Крижанич), либо согласно этнической (в условном смысле слова) принадлежности - словенский, русский, словенщина, литовский, сербский, иллирийский или иллирический и др. ${ }^{49}$ Разница между народным и книжным языком делалась далеко не всегда: книжный язык в большинстве случаев воспринимался как вариант “нашего языка”. Тем не менее случаи разграничения обоих идиомов в среде славянских книжников известны [Толстой 1988в: 112-119]. Кроме того, известно, что как к самостоятельному функциональному варианту к книжному языку славян относились и некоторые иностранцы. Классическим примером в этой связи стало наблюдение Генриха Лудольфа о разнице между “славянским” и русским языками. Особенная ценность этого наблюдения заключается в том, что оно базируется на высказываниях самих московитов: “. . . apud illos [Russos. - И. П.] dicitur, loquendum est Russice et scribendum est Slavonice (= cpeди русских говорится, что разговаривать следует по-русски, а писать пославянски)" ${ }^{\text {. }}$. То есть мы располагаем указаниями говорящих-пишущих

${ }^{48}$ На сегодняшний день самый ранний случай употребления данного глоттонима Г. Кайперт зафиксировал в датируемом 1810 г. переводе А. Х. Востоковым статьи Й. Добровского “Über die Altslawonische Sprache nach Schlözer” (“О древнеславянском языке по Шлёцеру”, 1806 г.) [KEIPERT 2006в: 304-305]. Это не означает, что Востоков был первым, кто ввел этот термин. Однако более ранние случаи его употребления пока что неизвестны, кроме того, очевидно, что Востоков назвал язык церковнославянским независимо от Копитара (1808 г.), который в своей переписке с Добровским название kirchenslavisch “нередко приводит [. . .] так, что создается впечатление, что прилагательное как термин само собой понятно и не нуждается ни в каких объяснениях" [IDEM 2006в: 304] (cp. [IDEM 2006A: 52-58], а также об истории термина: [IDEM 1998]).

49 См. [Толстой 1988А] и отдельные примеры с комментариями в [Успенский 2002: 389-390; KEIPERT 1988: 330-331 = 1991: 98; 2001A: 19; BUNČIĆ 2006: 137-140].

50 См. обстоятельный анализ в [Толстой 1988А: 109-111; УспЕнский 2002:366, 479-480]. 
на церковнославянском языке о том, что это - иной язык. Тем самым выполняется условие цитированной выше дефиниции понятия 'исторический язык', а именно - номинальная фиксация говорящими/пишущими факта существования языка.

Еще одна специфическая особенность, требующая объяснений, заключается в том, что как в собственно истории языка, так и в науке об истории языка церковнославянский язык имеет особый статус. Этот статус определяется, согласно Кайперту, тем, что, во-первых, это “язык без народа”, т. е. церковнославянский язык не принадлежит исключительно одному славянскому народу и ни один славянский народ не может идентифицировать себя исключительно с церковнославянским языкOM [KEIPERT 2014: 1212-1213]; во-вторых, это язык-конструкт, т. е., будучи корпусным языком (Korpussprache), он реконструируется исследователями на основании сохранившегося корпуса текстов, в котором он, в свою очередь, был по образцам сконструирован древними книжниками [IDEM 2001в: 373-374; 2014: 1238-1240]. Это искусственное образование ${ }^{51}$, а не естественный язык, тогда как термином исторический язык преимущественно обозначают именно естественные языки, которые используются не только как письменные, но и как разговорные. Однако, во-первых, в истории употребления церковнославянского языка пришло время (втор. пол. XVII в.), когда этот книжный идиом стал использоваться в качестве разговорного, когда на нем стали вестись научные дискуссии [УспЕнский 2002: 366, 479-480] или, по крайней мере, существовало представление о том, что на письменном языке можно также говорить ${ }^{52}$. Это - свидетельство иного отношения к языку, восприятие его как более полноценного языка. Во-вторых, как утверждал Косериу, исторический язык может функционировать как high variety и даже лишь как функциональный язык-вариант. Таким образом, и в этом отношении у нас есть основания применять термин исторический язык к церковнославянскому языку.

51 Ср. ссылку Кайперта [КеIPERT 2001в: 374] на работу ТруБЕцкого [1995: 168].

52 Ссылаясь на статью И. Ф. Голубева, в которой публикуется конспект ученой беседы Симеона Полоцкого, Епифания Славинецкого и Паисия Лигарида с Николаем Спафарием, Б. А. Успенский не обратил внимания на комментарий издателя о том, что “беседа велась на латинском языке”, а не на церковнославянском [ГолуБЕв 1971: 296]. Тем самым остается не доказанным, что церковнославянский язык мог использоваться в качестве языка ученых диспутов. Однако следует указать на еще один конспект беседы, а именно беседы Епифания Славинецкого и Симеона Полоцкого, зафиксированной в “Остене” [ОстЕн: 71-74]. У нас есть объективные основания сомневаться в подлинности этой беседы (доказательства будут приведены в отдельной работе; ср. позицию П. Бушковича, считающего все эти беседы фальсификацией [Bushкoviтcн 1992: 154]). Тем не менее конспект свидетельствует о том, что книжники XVII в. могли представить себе устный ученый спор по-церковнославянски. 
Рассматривать эволюцию церковнославянского языка через призму концепта 'исторический язык’ означает проследить, как с течением времени развивалось в обществе отношение к этому идиому как к самостоятельному языку. То есть нам предстоит ответить на следующий круг вопросов:

- Когда представители славянских языковых культур стали видеть в языковой форме, образец для подражания которой задавали церковные тексты, отдельную языковую систему, которая в определенных социокультурных сферах жизни может использоваться как самостоятельное средство коммуникации и нуждается в собственном имени, чтобы быть отграниченным от параллельно существующего коммуникативного средства, удовлетворяющего иной круг коммуникативных потребностей?

- Когда данная языковая форма развилась до такой степени, что в целях удовлетворения коммуникативных потребностей стали разграничиваться и намеренно варьироваться ее синтопические единства, т. е. региональные варианты?

- Когда коммуникативные потребности изменились настолько, что стала очевидной непрактичность их удовлетворения посредством книжного языка, поскольку этому не способствовала языковая компетенция - уровень владения и умения пользоваться этим идиомом - преимущественного большинства образующих синстратические единства социокультурных групп, которые также должны были быть вовлечены в коммуникацию?

- Когда внутри симфазических единств - групп жанровых образований, или, более широко, коммуникативных форм - с текстами, в той или иной степени воспроизводящими язык “книг церковного круга”, стали конкурировать тексты, использующие более простое коммуникативное средство, или же когда и для чего в рамках одного текста стали параллельно употребляться оба языковых кода?53

53 Термин языковой код здесь используется в значении, в котором он используется в прагма- и социолингвистике, а именно, как средство коммуникации. Таковым средством может быть как естественный, так и искусственный язык. Код членится на субкоды, т. е. на региональные и функциональные варианты одного и того же языка, которые, в свою очередь, подразумевают дальнейшее членение на более мелкие подсистемы [GUMPERZ 1962: 102; GLüск 2005: 323]. В свете социолингвистики эволюцию церковнославянского языка следовало бы представлять как эволюцию от субкода к коду. То есть вопрос звучал бы следующим образом: когда языковое расстояние (термин, введенный У. Вайнрайхом, см.: [GUMPERZ 1962: 103]) между письменным и устным субкодами “нашего языка” стало настолько отдаленным, что стало очевидным, что это два различных кода. 
Таковы некоторые из вопросов, на которые должна ответить социокоммуникативная и прагматическая история церковнославянского языка как 'исторического языка' в смысле Косериу.

Этот подход позволяет нам, оставаясь в рамках русской языковой истории, расширить концептуальные рамки наших представлений об истории русского языка, отказавшись от традиционного одностороннего отождествления процесса развития церковнославянской языковой культуры в XI-XVII вв. с историей русского литературного, или стандартного, языка. И дело здесь не только в том, что понятие 'исторический язык’ более широкое, чем понятие ‘стандартный язык’. Литературный, или стандартный, язык, согласно Косериу, является лишь одним из многочисленных звеньев в сложной системе исторического языка. Он представляет собой “образцовый” уровень развития общего, т. е. национального, языка, уровень, отражающий его социокультурную норму ${ }^{54}$.

Рассматривая церковнославянский язык как 'исторический язык', мы подходим к этому идиому как к факту или событию русской языковой истории. Такими же фактами-событиями в ней были греческий язык, латинский язык, польский язык и т. д., а вместе с ними и собственно русский язык. Все они также являются самостоятельными 'историческими языками', которые в истории русского языка использовались как функциональные или социальные языки-варианты. Каждый из них функционировал в определенных сферах: греческий был языком церкви, латинский был языком дипломатии, на польском языке, среди прочего, обменивались дружескими письмами проживающие в Москве питомцы Киево-Могилянской коллегии (Симеон Полоцкий, Димитрий Ростовский, Стефан Яворский и др.), русский был в первую очередь языком повседневного общения, но также и языком административной сферы и т. д. Все они наряду с церковнославянским языком могли применяться как в устной, так и в письменной коммуникации.

Отказавшись от традиционных представлений о том, что русским литературным языком Средневековья был язык церковнославянский, мы покажем, насколько гетерогенной была русская языковая история, и начнем представлять ее как историю фактов и событий, соотносимых с фактами и событиями отечественной истории.

${ }^{54}$ Cp. “... in einer Gemeinsprache kann man ferner eine Stufe unterscheiden, die ihre sozialkulturelle Norm darstellt, die «Standardsprache», das, was ich das «Exemplarische» einer Sprache nenne" [Coseriu 1988: 52]. 


\section{Библиограсьия}

АЛЕКСЕЕВ 1980A

АЛЕксевв А. А., “Предисловие”, в: [СоболЕвский 1980: 3-20]. 1980Б

АЛЕКСеЕв А. А., “Комментарий”, в: [СоБолЕвский 1980: 159-189]. 1989

АлексеЕв А. А., “[Рец.:] Толстой Н. И. История и структура славянских литературных языков”, Вопросы языкознания, 4, 1989, 149-155. 2013

АлЕкСевв А. А., Очерки и этюды по истории литературного языка в России, С.-Петербург, 2013.

БAC, 7

Большой академический словарь русского языка, 7: И - Каюр, Москва, С.-Петербург, 2007. Билярский $1847 / 48$

Билярскій П. С., Судьбы церковнаго языка. Историко-филологическія изслпдованія, 1-2, С.-Петербургъ, 1847-1848.

БРОКЗАУЗ/ЕФРОН, 22А

БрокГАУзъ Ф. А., ЕФронъ, И. А., Энциклопедическій словаръ, 22а: Оуэнъ - Патентъ о поединкахъ, С.-Петербургъ, 1897.

БудДЕ 1908

[БудДЕ Е.], Очеркъ исторіи современнаго литературнаго русскаго языка (XVII-XIX впкъ) (= Энциклопедія славянской филологіи, 1), С.-Петербургъ, 1908.

Будилович 1887

Будиловичъ А. С., “А. С. Пушкинъ въ исторіи большихъ литературныхъ языковъ”, Извпстіл С.-Петербургскаго Слав Анскаго благотворительнаго общества, 4, 1887, 206 209.

1892

Будиловичъ А. С., Общеслав жнскій жзыкъ въ ряду другихъ общихъ языковъ древней и новой Европы, 1: Очерки образованія общихъ языковъ южной и западной Европы, 2: Зарожденіе общаго языка на славянскомъ Востокп, Варшава, 1892.

1893

Будиловичъ А. С., “Образованіе литературныхъ языковъ и ихъ значеніе въ исторіи”, Ученыя записки Императорскаго Юрьевскаго университета, 2, 1893, 71-88.

БУЛАНИн 1987

БулАнин Д. М. “Предисловие”, в: Словарь книжников и книжности Древней Руси, 1: XIпервая половина ХIV в., Ленинград, 1987.

БуСлАЕв 1861

БУслАевъ Ө. С., Учебныя руководства для военно-учебныхъ заведеній. Историческая христоматія церковно-славянскаго и древне-русскаго языковъ (= Slavica-Reprint, 56), Москва, 1861.

ВВЕДЕНСКИЙ 1933

ВведЕНСКий Д. Н., “Фердинанд де Соссюр и его место в лингвистике”, в: Р. И. ШоР, общ. ред., Курс общей лингвистики, изданный Ш. Бальи и А. Сещеэ при участии А. Ридлингер, пер. со 2-го франц. изд-я, Москва, 1933.

ВЕНГЕРОВ 1897

ВенгеРовъ С. А., Критико-біографическій словарь русскихъ писателей и ученыхъ (отъ начала русской образованности до нашихъ дней), 5, С.-Петербургъ, 1897. 
ВЕРЕЩАГИН 1989

ВЕРЕЩАГИн Е. М., “Проблемы истории древнеславянского и русского литературного языков (К выходу в свет книги акад. Н. И. Толстого)”, Известия АН СССР. Серия литературы и языка, 48/2, 1989, 126-136.

ВИНОГРАДОВ 1978

ВиногРАдов В. В., Избранные труды. История русского литературного языка, Москва, 1978.

1982

ВИНоградов В. В., Очерки из истории литературного языка ХVII-XIX вв., Москва, 1982.

Винокур 1959

Винокур Г. О., “О задачах истории языка”, в: ОН жЕ, Избранные труды по русскому языку, Москва, 1959, 207-226.

ГолУБев 1971

Голуьев И. Ф., “Встреча Симеона Полоцкого, Епифания Славинецкого и Паисия

Лигарида с Николаем Спафарием и их беседа”, в: Труды Отдела древнерусской

литературы, 26, Ленинград, 1971, 294-301.

Горшков 1983

Горшков А. И., Теоретические основы истории русского литературного языка, Москва, 1983.

1984

Горшков А. И., Теория и история русского литературного языка, Москва, 1984.

Дурново 1924/1962

Дурново Н., Очерк истории русского языка (= Slavistische Drukken en Herdrukken, 22),

'S-Gravenhage, 1962 [первое издание: Москва, Ленинград, 1924].

ЕРОФЕЕВА 2001

ЕРОФЕЕВА И. В., “Применение дихотомического принципа внутренней и внешней истории языка И. А. Бодуэна де Куртэне к изучению памятников древнерусской письменности", в: К. Р. ГАлиуллин, Г. А. НиколАЕв, общ. ред., Бодуэновские чтения: Бодуэн де Куртенэ и современная лингвистика: Международная научная конференция (Казань, 11-13 декабря 2001 г.): Труды и материалы, 1, Казань, 2001, 68-69.

Живов 1996

Живов В. М., Язык и культура в России ХVIII века, Москва, 1996.

ЖУРАВЛЕВЫ 2005

ЖУРАВЛЕВ В. К., ЖУРАВЛЕВ И. В., “Замечания о предмете истории Литературного ЯзыКа", в: Е. Ф. БУддЕ, Очерк истории современного литературного языка (XVII-XIX век), изд. 2-е, Москва, 2005, III-VIII.

ЗАХАРОВА 2012

ЗАХАРОВА Ю. Г., История русского языка. Учебное пособие для практических занятий, Москва, 2012.

ЗВЕГИНЦЕВ 1963

Звегинцев В., “Теоретические аспекты причинности языковых изменений”, в: Новое в лингвистике, 3, Москва, 1963, 125-142.

ИСАЧЕНКО 1958

ИСАченко А. В., “Ответ на вопрос §3 Анкеты к IV МСС”, Вопросы языкознания, 3, 1958, 42.

КАМЧАТНОВ 2008

КАмЧАТНов А. М., История русского литературного языка: ХI - первая половина ХІХ века, Москва, 2008. 
КАРСКИЙ 1962

КАРский Е. Ф., "Главнейшие течения в русском литературном языке. Вступительная лекция по русскому языку лектора Варшавского университета Е. Ф. Карского, произнесенная 27 февраля 1893 года", в: Он жЕ, Труды по белорусскому и другим славянским языкам, Москва, 1962, 130-139.

КолЕсов 2005

Колесов В. В., История русского языка, Москва, С.-Петербург, 2005.

КОСЕРИУ 1963

КосеРиУ Э., “Синхрония, диахрония и история”, в: Новое в лингвистике, 3, Москва, 1963, 143-343.

КУЗНЕцОв 2004

КузНЕцов П. С., “Предисловие”, в: О. ГуйЕР, Введение в историю чешского языка, изд-е 2-е, Москва, 2004, 3-7.

МЕДЫНЦЕвА 2000

Медынцева А. А., Грамотность в Древней Руси (По памятникам эпиграфики X - первой половины ХІІІ века), Москва, 2000.

НАРУМОВ 2005

НАРУмов Б. П., “«Архитектура языка» в концепции Э. Косериу”, в: О. М. МунгАловА, Ю. Л. ОБОЛЕНСКАЯ, Ю. А. КАРПОВА, сост., Вопросы иберо-романской филологии, 7 (Посвящается 80-летию профессора В. С. Виноградова), Москва, 2005, 140-145.

НИКОЛАЕВА 2003

НиколАЕвА Т. М., “Некоторые общетеоретические идеи языковедения в трудах И. А. Бодуэна де Куртенэ”, в: К. Р. ГАлиуллин, Г. А. НиколАЕв, общ. ред., II Международные Бодуэновские чтения: Казанская лингвистическая школа: традищии и современность (Казань, 11-13 декабря 2003 г.). Труды и материалы, 1, Казань, 2003, $21-25$.

ОСТЕН

Остенъ: Памятникъ русской духовной письменности XVII впка, Казань, 1865.

ПоЛИВАНОВ 1960

ПоливАнов Е. Д., “Историческое языкознание и языковая политика”, в: В. А. ЗвЕГинцеВ, История языкознания ХІХ и ХХ веков в очерках и извлечениях, 2, Москва, 1960, 263-278.

Пыпин 1890

Пыпинъ А. Н., Исторія русской этнографіи, 1: Общій обзоръ изученій народности. Этнографія великорусская, С.-Петербургъ, 1890.

СоБолевский 1962

СоБолевский А. И., Лекиии по истории русского языка, изд-е 4-е (= Slavistische Drukken en Herdrukken, 37), 'S-Gravenhage, 1962.

1980

СоБолевский А. И., История русского литературного языка, изд. подгот.

А. А. АЛЕКСеЕв, Ленинград, 1980.

дЕ Соссюр 2006

де Соссюр Ф., Курс общей лингвистики, пер. со 2-го франц. изд-я А. М. СухотинА, под ред. и с примеч. Р. И. Шор, изд-е 3-е стер., Москва, 2006.

Толстой 1988А

Толстой Н. И., История и структура славянских литературных языков, Москва, 1988. 1988в

Толстой Н. И., “Старинные представления о народно-языковой базе древнеславянского литературного языка (XVI-XVII вв.)”, в: [Толстой 1988A: 108-127]. 
1992

Толстой Н., “Взгляды А. Н. Пыпина на историю русского литературного языка

(Страничка из истории русской лингвистики)”, in: W. MoskovicH ET AL., eds., Russian

Philology and History: In Honor of Professor Victor Levin, Jerusalem, 1992, 156-169.

ТруьЕцкой 1995

ТруБецкой Н. С., “Общеславянский элемент в русской культуре”, в: Он жЕ, История.

Культура. Язык, вступ. ст. Н. И. Толстого, Л. Н. ГумилЕВА; сост., подг. текста и коммент.

В. М. ЖивовА, Москва, 1995, 162-208.

УСПЕНСКИЙ 1995/1997

УспЕнский Б. А., “История русского литературного языка как межславянская

дисциплина”, Вопросы языкознания, 1, 1995, 80-92 [переиздание в: Он жЕ, Избранные

труды, 3: Общее и славянское языкознание, Москва, 1997, 121-142].

2002

УспЕнский Б. А., История русского литературного языка (XI-XVII вв.), изд-е 3-е, испр. и доп., Москва, 2002.

ХуJEP 1935

ХујеР О., Увод у историју словенских језика, превео Х. БАРИЋ (= Лингвистичка

библиотеке, 1), Београд, 1935.

ЧЕРЕПАНОВ 2003

ЧЕРЕПАНОв М. В., “И. А. Бодуэн де Куртенэ о языке как динамической системе”, в:

К. Р. ГАлиуллин, Г. А. НиколАЕв, общ. ред., ІІ Международные Бодуэновские чтения: Казанская лингвистическая школа: традиции и современность (Казань, 11-13 декабря 2003 г.). Труды и материалы, 1, Казань, 2003, 29-32.

ШАРАДЗЕНИДЗЕ 1980

ШАРАДЗЕНИДЗЕ Т. С., Лингвистическая теория И. А. Бодуэна де Куртенэ и ее место в языкознании ХІХ-ХХ веков, Москва, 1980.

Aitchison 2013

Aitchison J., Language Change: Progress or Decay? 4th ed., Cambridge, etc., 2013.

Albrecht 2003

Albrecht J., "Die Berücksichtigung des Faktors «Übersetzung» in der Sprachgeschichtsschreibung," in: A. GIL, C. Schмiтt, Hrsg., Aufgaben und Perspektiven der romanischen Sprachgeschichte im dritten Jahrtausend. Akten der gleichnamigen Sektion des XXVII. Deutschen Romanistentages. München (7.-10. Oktober 2001), Bonn, 2003, 1-20.

BÄHLER 2004

BÄHLER U., Gaston Paris et la philologie romane (= Publications romanes et françaises, 234), Genève, 2004.

BAudouin DE COURTENAY 1974-1990

Baudouin de Courtenay J. N., Dzieta wybrane, 1-4, Warszawa, 1974-1990.

BAUM 1987

BAUM R., Hochsprache. Literatursprache. Schriftsprache: Materialien zur Charakteristik von Kultursprachen (= Impulse der Forschung, 49), Darmstadt, 1987. 2003

BAuM R., "Periodisierung in der romanistischen Sprachgeschichtsschreibung," in: HSK, 23/1, 45-52.

BERSCHIN 2001

Berschin H., "Interne und externe Sprachgeschichte," in: $L R L, 1 / 2,628-637$. 2003

BERSCHIN H., "Synchronie und Diachronie in der romanistischen Sprachgeschichtsforschung," in: HSK, 23/1, 32-38. 
BERUTTO 2004

Berutto G., "Sprachvarietät - Sprache (Gesamtsprache, historische Sprache)," in: HSK, ${ }^{23} / 1$, 188-195.

BESCH 1982

BESCH W., "Dialekt, Schreibdialekt, Schriftsprache, Standardsprache," in: HSK, 1/1, 961-990.

BLUMENTHAL 2003

Blumenthal P., "Der Begriff der externen und internen Sprachgeschichte in der Romanistik," in: $H S K, 23 / 1,38-45$.

BOLTEN 1998

BoLTen J., "Deutsche Sprachgeschichte und Wirtschaftsgeschichte," in: HSK, 2/1, 123-138.

BRANG/ZÜLLIG 1981

BRAng P., ZüLlig M., Kommentierte Bibliographie zur Slavischen Soziolinguistik, unter Mitwirk. v. K. BRANG, 1-3 (= Slavica Helvetica, 17), Bern, etc., 1981.

BROZOVIĆ 1970

BRozović D., Standardni jezik. Teorija, usporedbe, geneza, povijest, suvremena zbilja, Zagreb, 1970.

BRUNOT 1896A

Brunot F., "Introduction. Origines de la langue française," in: [Petit De Julleville 1896, 1: I-LXXX]. $1896 \mathrm{~B}$

BRunot F., "La langue française jusqu'à la fin du XIVe siècle," in: [Petit De Julleville 1896, 2: 446-553]. 1966-1972

BRunot F., Histoire de la langue française. Des origines à nos jours, 1-13, Paris, Colin, 1966-1972.

BUDZIAK 1997

Budziak R., Jan Baudouin de Courtenay als Soziolinguist und Sprachsoziologe, Bamberg, 1997.

BUNČIĆ 2006

BunčIć D., Die ruthenische Schriftsprache bei Ivan Uževyč unter besonderer Berücksichtigung der Lexik seines Gesprächsbuchs "Rozmova/Besěda”. Mit Wörterverzeichnis und Indizes zu seinem ruthenischen und kirchenslavischen Gesamtwerk (= Slavistische Beiträge, 447), München, 2006.

BushKovitch 1992

Bushrovitch P., Religion and Society in Russia. The Sixteenth and Seventeenth Centuries, New York, Oxford, 1992.

BUßMANN 2002

Bußmann H., Hrsg., Lexikon der Sprachwissenschaft, 3. Aufl., Stuttgart, 2002.

CARTER 1998

CARTER R. “Literary Language,” in: J.-L. Mey, ed., Concise Encyclopedia of Pragmatics, Amsterdam, etc., 1998, 520-522.

CHERUBim 1978

Cherubim D., "Zum Programm einer historischen Sprachpragmatik," in: H. SitTA, Hrsg., Ansätze zu einer pragmatischen Sprachgeschichte. Zürcher Kolloquium (= Reihe Germanistische Linguistik, 21), Tübingen, 1980, 3-21. 1998

Cherubim D., "Sprachgeschichte im Zeichen der linguistischen Pragmatik," in: HSK, 2/1, 538-550.

COSERIU 1967/1972

Coseriu E., "Georg von der Gabelentz et la linguistique synchronique,” Word, 23, 1967, 74-100 (немецкое издание: IDEM, "Gabelentz und die synchronische Sprachwissenschaft," in: [voN DER GABELENTZ 1972: 3-35]). 
1988

COSERIU E., "«Historische Sprache» und «Dialekt»," in: Energeia und Ergon: Sprachliche Variation - Sprachgeschichte - Sprachtypologie, 1: Schriften von Eugenio Coseriu (= Tübinger Beiträge zur Linguistik, 300), Tübingen, 1988, 45-61. 2007

Coseriu E., Sprachkompetenz: Grundzüge der Theorie des Sprechens, 2., durchges. Aufl., bearb. u. hrsg. v. H. WeBER (= Tübinger Beiträge zur Linguistik, 508), Tübingen, 2007.

DANEŠ 1988

DANEŠ F., "Herausbildung und Reform von Standardsprachen," HSK, 3/2, 1506-1516. 2006

DANEŠ F., "Herausbildung und Reform von Standardsprachen und Destandardisierung," HSK, 3/3, 2197-2209.

De MaUro 1986

De Mauro T., Storia linguistica dell'Italia unita (= Biblioteca universale Laterza, 88), 3rd ed., Bari, 1986.

Devoto 1940

Devoto G., Storia della lingua di Roma (= Storia di Roma, 23), Bologna, 1940. 1951

Devoto G., I fondamenti della storia linguistica (= Biblioteca enciclopedica Sansoniana, 9), Firenze, 1951.

Di CESARE 1998

Di Cesare D., "Einleitung," in: [von Humboldt 1998: 9-128].

DRÄXLER 1989

DrÄXLER H.-D., Soziolinguistik, Pragmalinguistik und Sprachgeschichte. Die Bedeutung soziound pragmalinguistischer Parameter für eine Theorie des Sprachwandels (= Impulse. Didaktisches Zentrum der Johann Wolfgang Goethe-Universität Frankfurt, 9), Darmstadt, 1989.

Droixhe/Dutilleul 1990

Droixhe D., Dutilleul TH., "Le français: Histoire externe de la langue," in: $L R L, 5 / 1,437-471$.

ERNST ET AL. 2003

ERnst G., Glessgen M.-D., Schmitt Ch., Schweickard W., "Romanistik und Sprachgeschichtsschreibung," in: HSK, 23/1, 1-15.

FLYDAL 1952

FLYDAL L., "Remarques sur certains rapports entre le style et l'état de langue," in: Norsk Tidsskrift for Sprogvidenskap, 16, 1952, 241-258.

FRANKLIN 2002

FrANKLIN S., Writing, Society and Culture in Early Rus, c. 950-1300, Cambridge, 2002 (русское издание: ФРАнклин С., Письменность, общество и культура в Древней Руси: (Около $950-$ 1300 г2.), пер. Д. М. БулАнинА, С.-Петербург, 2010).

VON DER GABELENTZ 1972

VON Der Gabelentz G., Die Sprachwissenschaft, ihre Aufgaben, Methoden und bisherigen Ergebnisse, mit einer Studie v. E. Coseriu, 2. Aufl. (= Tübinger Beiträge zur Linguistik, 1), Tübingen, 1972.

GARDT ET AL. 1999

Gardt A., Hass-Zumkehr U., Roelke Th., Hrsg., Sprachgeschichte als Kulturgeschichte (= Studia Linguistica Germanica, 54), Berlin, New York, 1999.

GIOVANARDi 1999

GiovanARDI C., "Soziolinguistik und italienische Sprachgeschichte: einige Betrachtungen zur Debatte im 16. Jahrhundert," Sociolinguistica, 13, 1999, 17-26. 
GLÜCK 2005

GLÜCK H., Hrsg., Metzler Lexikon Sprache, 3., neubearb. Aufl., Stuttgart, Weimar, 2005.

GONZÁLEZ 1992

GonZÁLEz C.-H., “Historia lingüística externa,” in: LRL, 6/1, 406-414.

GRÖBER 1888A

GRÖBER G., Hrsg., Grundriss der romanischen Philologie, 1: Geschichte und Aufgabe der romanischen Philologie. Quellen der romanischen Philologie und deren Behandlung. Romanische Sprachwissenschaft. Register, Strassburg, 1888. 1888B

GRÖBER G., "Die romanischen Sprachen. 1. Ihre Einteilung und äussere Geschichte,” in: [GRÖBER 1888a: 415-437]. $1888 \mathrm{C}$

GRÖBER G., "Die Behandlung der Quellen. Methodik und Aufgaben der sprachwissenschaftlichen Forschung,” in: [GRÖBER 1888a: 209-250]. 1888D

GRÖBER G., “Aufgabe und Gliederung der romanischen Philologie,” in: [GRÖBER 1888a: 140-154].

GUMPERZ 1962

Gumperz J.-J., "Types of Linguistic Communities," in: Idem, Language and Social Groups, A.-S. DIL, ed., Stanford, 1971, 97-113 (русский перевод: ГАмпЕРц Дж. Дж., “Типы языковых обществ”, в: Новое в лингвистике, 7: Социолингвистика, Москва, 1975, 182-198).

HAFNER 2006

HAFNER J., Ferdinand Brunot und die nationalphilologische Tradition der Sprachgeschichtsschreibung in Frankreich (= Romanica Monacensia, 73), Tübingen, 2006.

HAVRÁNEK 1963

Havránek B., Studie o spisovném jazyce, Praha, 1963.

HiLDENBRANDT 1972

HiLdenBRANDT E., Versuch einer kritischen Analyse des "Cours de linguistique générale" von Ferdinand de Saussure (= Marburger Beiträge zur Germanistik, 36), Marburg, 1972.

HORÁLEK 1976

HoRÁLeK K., "Zur Geschichte der Prager Linguistik und ihrer internationalen Wirkung," in: [SCHARNHORST/ISING 1976/1982, 1: 24-42].

HORROCKS 1997

Horrocks G., Greek: A History of the Language and Its Speakers, London, New York, 1997.

HSK = HANDBÜCHER ZUR SPRACH- UND KOMMUNIKATIONSWISSENSCHAFT: , 1 (= HSK, $1 / 1$; HSK, $1 / 2$ )

Besch W., Knoop U., PutschKe W., Wiegand H. E., Dialektologie. Ein Handbuch zur deutschen und allgemeinen Dialektforschung, Bd. 1.1, Berlin, New York, 1982; Bd. 1.2, Berlin, New York, 1983.

$-2 / 1$

Besch W., Betten A., Reichmann O., Sonderegger S., Hrsg., Sprachgeschichte. Ein Handbuch zur Geschichte der deutschen Sprache und ihrer Erforschung, Bd. 2.1, zweite, vollständig neu bearb. u. erw. Aufl., Berlin, New York, 1998. , $3\left(=3.2,{ }^{2} 3.1,{ }^{2} 3.3\right)$

Ammon U., Dittmar N., Mattheier K.-J., Hrsg., Sociolinguistics. An International Handbook of the Science of Language and Society, Bd. 3.2, Berlin, New York, 1988; Bd. 3.1 u. 3.3, zweite, vollständig neu bearb. u. erw. Aufl., Berlin, New York, 2006.

$23 / 1$

ERnSt G., GLEßgen M.-D., SCHMitT CH., Romanische Sprachgeschichte. Ein internationales Handbuch zur Geschichte der romanischen Sprachen, Bd. 1, Berlin, New York, 2003. 
HUJER 1924

Hujer O., Úvod do dějin jazyka českého, druhé vydání, Praha, 1924.

VON HUMBOLDT 1998

von Humbold W., Über die Verschiedenheit des menschlichen Sprachbaues und ihren Einfluß auf die geistige Entwickelung des Menschengeschlechts, hrsg. v. D. Di Cesare, Paderborn etc., 1998.

JÄGER 1998

JÄGER L., "Das Verhältnis von Synchronie und Diachronie in der Sprachgeschichtsforschung," in: $H S K, 2 / 1,816-824$.

JEDLIČKA 1978

JedličKa A., Spisovnýjazyk v současné komunikaci, Praha, 1978.

JEDLIČKA 1982

JEDLIČKA A., "Theorie der Literatursprache," in: [SCHARNHORST/ISING 1976/1982, 2: 40-91].

KEIPERT 1982

KEIPERT H., "Russische Sprachgeschichte als Übersetzungsgeschichte," in: W. GIRKE, Hrsg., Slavistische Linguistik 1981. Referate des VII. Konstanzer Slavistischen Arbeitstreffens. Mainz 30.9.-2.10.1981 (= Slavistische Beiträge, 160), München, 1982, 67-101. 1984

KeIPERT H., “[Rez.:] Горшков В. И. Теоретические вопросы истории русского литературного языка. Москва 1983,” Russian Linguistics, 8, 1984, 159-166. 1985

KeIPERT H., "Old and New Problems of the Russian Literary Language (Arguments for a New Kind of Russian Linguistic History)," in: W. GIRKE, D. Worth, eds., The Formation of the Slavonic Literary Languages. Proceedings of a Conference Held in Memory of Robert Auty and Anne Pennington at Oxford 6-10 July 1981 (= UCLA Slavic Studies, 11), Columbus (OH), 1985, $215-224$. 1988

KeIPERT H., "Die Christianisierung Russlands als Gegenstand der russischen Sprachgeschichte," in: K. Ch. Felmy, G. Kretschmar, F. von Lilienfeld, C.-J. Roepke, Hrsg., Tausend Jahre Christentum in Russland. Zum Millennium der Taufe der Kiever Rus', Göttingen, 1988, 313-346 (русский перевод: [КеIPERT 1991]). 1991

КАЙПЕРт Г., “Крещение Руси и история русского литературного языка”, Вопросы языкознания, 5, 1991, 86-112. 1996

KeIPERT H., "A. Chr. Vostokov, die deutsche Slavenkunde und das Altbulgarische,"

Palaeobulgarica = Старобългаристика, 20/1, 1996, 99-114. 1998

KeIPeRt H., "Cerkovnoslavjanskij: eine Sprachbezeichnung als Problem der Wortbildungslehre,” в: М. Я. ГловинскАЯ, отв. ред., Лики языка: К 45-летию научной деятельности Е. А. Земской, Москва, 1998, 143-152. 1999A

KeIPERT H., “A. S. Budilovičs «Общеславянский язык» (1892). Ein Rückblick,” in: K. Grünberg, W. Ротthoff, Hrsg., Ars Philologica. Festschrift für Baldur Panzer zum 65. Geburtstag, Frankfurt a. M., etc., 1999, 69-80. 1999B

Keipert H., "Die Kirchenslavisch-These des Cercle linguistique de Prague," in: E. Hansack, W. Koschmal, N. NÜBleR, Hrsg., Festschrift für Klaus Trost zum 65. Geburtstag (= Die Welt der Slaven. Sammelbände, 5), München, 1999, 123-133. 
$1999 \mathrm{C}$

KeIPERT H., “Geschichte der russischen Literatursprache," in: H. JaCHnOw, Hrsg., Handbuch der sprachwissenschaftlichen Russistik und ihrer Grenzdisziplinen (= Slavistische Studienbücher, N. F., 8), Wiesbaden, 1999, 726-779. $2001 \mathrm{~A}$

KeIPERT H., “«Rozmova/Besěda»: Das Gesprächsbuch Slav. № 7 der Bibliothèque nationale de France," Zeitschrift für Slavische Philologie, 60/1, 2001, 9-40. 2001B

KeIPeRt H., “Kirchenslavisch als Konstrukt,” Slavia, 70, 2001, 373-381. 2003

KEIPERT H., "Die romanischen Sprachen in der slavistischen Sprachgeschichtsschreibung," in: HSK, 23/1, 470-476. $2004 \mathrm{~A}$

KeIPERT H., “«Über die Altslawonische Sprache nach Schlözer, mit Anmerkungen von J. D. Dobrovskýs» Schlözer-Kritik im «Slavin» und ihre Folgen,” in: V. VAVŘínEK, H. GLADKOVA, K. SKWARSKA, vyd., Josef Dobrovský. Fundator studiorum slavicorum. Příspěvky z mezinárodní vědecké konference v Praze 10.-13. června 2003, Praha, 2004, 261-269. 2004B

KeIPeRt H., "August Ludwig Schlözer i «Słownik języka polskiego» Samuela Bogumiła Lindego," Prace filologiczne, 49, 2004, 169-180. 2006A

KeIPERT H., Das "Sprache"-Kapitel in August Ludwig Schlözers "Nestor" und die Grundlegung der historisch-vergleichenden Methode für die slavische Sprachwissenschaft. Mit einem Anhang Josef Dobrovskýs "Slavin"-Artikel "Über die Altslawonische Sprache nach Schlözer" und dessen russische Übersetzung von Aleksandr Chr. Vostokov, hrsg. in Verbindung mit M. Š. FAJNŠTEJN (= Abhandlungen der Akademie der Wissenschaften zu Göttingen, Philologisch-Historische Klasse, 3. Folge, 276), Göttingen, 2006. 2006B

KEIPERT H., "Востоков и Шлецер (О началах сравнительно-исторического метода в славянском языкознании),” Russian Linguistics, 30/3, 2006, 303-319. $2006 \mathrm{C}$

KeIPERT H., “Cerkovnoslavjanskij in verordnetem Vergessen,” in: M. JESENŠEK, Z. ZoRKo, Hrsg., Jezikovna predanost. Akademiku prof. dr. Jožetu Toporišiču ob 80-letnici (= Zora, 44), Maribor, 2006, 129-145. 2008

KeIPERT H., “[Rez.:] Ian Press: A History of the Russian Language and Its Speakers. München: LINCOM Europa 2007. XII, 362 S. (LINCOM Studies in Slavic Linguistics. 26.)," Die Welt der Slaven, 53/1, 202-206. 2014

KeIPERT H., "Altkirchenslavisch und Kirchenslavisch," in: K. Gutschmidt, S. Kempgen, T. BERger, P. Kosta, Hrsg., Die slavischen Sprachen. Ein internationales Handbuch zu ihrer Struktur, ihrer Geschichte und ihrer Erforschung (= HSK, 32/2), Berlin, New York, 2014, 12111252.

KELLER 2003

KeLLER R., Sprachwandel. Von der unsichtbaren Hand in der Sprache, 3. Aufl. (= UTB, 1567), Tübingen, Basel, 2003.

KNOOP 1982

Knoop U., "Das Interesse an den Mundarten und die Grundlegung der Dialektologie," in: HSK, $1 / 1,1-23$. 


\section{Косн 1988}

Косн P., "Italienisch: Externe Sprachgeschichte I," in: $L R L, 4,343-360$.

KoEDER 1999

Koeder A., Von Ferdinand de Saussure zu einer formalen diachronischen Semantik

(Inauguraldissertation zur Erlangung der Doktorwürde, Konstanz, 1999).

KNoOP 1982

KNoop U., "Das Interesse an den Mundarten und die Grundlegung der Dialektologie," in: HSK, $1 / 1,1-23$.

LABOV 1994

Labov W., Principles of Linguistic Change, 1: Internal Factors (= Language in Society, 20), Oxford, 1994.

2001

LABov W., Principles of Linguistic Change, 2: Social Factors (=Language in Society, 29), Oxford, 2001.

\section{LEITH 1997}

Leith D., A Social History of English, London, New York, 1997.

LEWANDOWSKI 1990

LEWANDOWski Th., Linguistisches Wörterbuch, 5. Aufl., 3 Bde. (= UTB, 1518), Heidelberg, Wiesbaden, 1990.

LRL = Holtus G., Metzeltin M., Schmitt Ch., Hrsg., LeXikON DER ROMANistischen LiNGUisTiK: $1 / 2$

Methodologie (Sprache in der Gesellschaft / Sprache und Klassifikation / Datensammlung und -verarbeitung), 1/2, Tübingen, 2001.

$-, 3$

Die einzelnen romanischen Sprachen und Sprachgebiete von der Renaissance bis zur Gegenwart. Rumänisch, Dalmatisch/Istroromanisch, Friaulisch, Ladinisch, Bündnerromanisch, 3, Tübingen, 1989.

Italienisch, Korsisch, Sardisch, 4, Tübingen, 1988.

$-5 / 1$

Französisch, Okzitanisch, Katalanisch, 5/1, Tübingen, 1990.

$-5 / 2$

Okzitanisch, Katalanisch, 5/2, Tübingen, 1990.

$-6 / 1$

Aragonesisch/Navarresisch, Spanisch, Asturianisch/Leonesisch, 6/1, Tübingen, 1992.

, 6/2

Galegisch, Portugiesisch, 6/2, Tübingen, 1994.

LÜDTKE 1999

LÜDTKE J., "Zu den Aufgaben der spanischen Sprachgeschichtsschreibung," Sociolinguistica, 13, 1999, 27-50.

MATTHEIER 1988

MATtHeIR K.-J., “Das Verhältnis von sozialem und sprachlichem Wandel,” in: HSK, 3/2, 1430 1452.

MATTHEIER 1998

Mattheier K. J., "Allgemeine Aspekte einer Theorie des Sprachwandels," in: HSK, 2/1, 824836. 
MetZeLtin/GritZKY 2003

Metzeltin M., GritZKy N., "Sprachgeschichtsschreibung: Möglichkeiten und Grenzen,” in: HSK, 23/1, 15-31.

MEYER 1888

MEYER W., “Die lateinische Sprache in den romanischen Ländern,” in: [GRÖBER 1888A: 377-382].

MILROY 1992

Milroy J., Linguistic Variation and Change: On the Historical Sociolinguistics of English (= Language in Society, 19), Oxford, 1992.

MOSER 2000

Moser M., "Kleine Sprachgeschichte des Ukrainischen der mittleren Periode," in: J. BestersDILGER, Hrsg., Sprache und Literatur der Ukraine zwischen Ost und West = Mова ma rimepamypa України між сходом і заходом, Bern, etc., 2000, 127-144.

Mugdan 1984

Mugdan J., Jan Baudouin de Courtenay (1845-1929): Leben und Werk, München, 1984.

OSTHOFF 1883

Osтноff H., Schriftsprache und Volksmundart: Vortrag, gehalten im Museum zu Heidelberg am 14. December 1878 (= Sammlung gemeinverständlicher wissenschaftlicher Vorträge, Ser. 18, Heft 411), Berlin, 1883.

PARIS 1897/1909

PARIS G., "Histoire de la langue française: Histoire de la langue française, par M. Ferdinand Brunot, maître de conférences à la Faculté des lettres de Paris. (Fait partie de l'Histoire de la langue et de la littérature française des origines à 1900, publiée sous la direction de L. Petit de Julleville, professeur à la Faculté des lettres de Paris. Paris, Colin, 1896 et ann. suiv., in$8^{\circ}$.)," in: IDEM, Mélanges linguistiques: latin vulgaire et langues romanes, langue française, notes étymologiques, appendice, index, publiès par M. Roques, Paris, 1909, 174-230 (впервые в: Journal des Savants, 1897, Septembre, 542-555; Octobre, 596-613; Novembre, 659-675).

Paul 1920

Paul H., Prinzipien der Sprachgeschichte, 5. Aufl., Darmstadt, 1920.

Petit de Julleville 1896

Petit de Julleville L., publ., Histoire de la Langue et de la Littérature française des Origines à 1900, 1-2: Moyen Age (des Origines à 1500), Paris, 1896.

VON POLENZ 1991-1994

von Polenz P., Deutsche Sprachgeschichte vom Spätmittelalter bis zur Gegenwart, 1: Einführung. Grundbegriffe. Deutsch in derfrühbürgerlichen Zeit, Berlin, New York, 1991; 2: 17. und 18. Jahrhundert, Berlin, New York, 1994.

1998

von Polenz P., "Deutsche Sprache und Gesellschaft in historischer Sicht," in: HSK, 2/1, 41-54. 2002

von Polenz P., “Sprachgeschichte und Gesellschaftsgeschichte von Adelung bis heute," in:

D. Cherubim, K. Jakob, A. Linke, Hrsg., Neue deutsche Sprachgeschichte. Mentalitäts-, kulturund sozialgeschichtliche Zusammenhänge (= Studia Linguistica Germanica, 64), Berlin, New York, 2002, 1-23.

Polzin-Haumann 2006

Polzin-Haumann C., Sprachreflexion und Sprachbewusstsein. Beitrag zu einer integrativen Sprachgeschichte des Spanischen im 18. Jahrhundert (= Bonner romanistische Arbeiten, 91), Frankfurt a. M., 2006.

PRESS 2007

PRESS I., A History of the Russian Language and Its Speakers (= LINCOM Studies in Slavic 
Linguistics, 26), München, 2007.

REICHMANN 1998

ReIchmann O., "Sprachgeschichte: Idee und Verwirklichung," in: HSK, 2/1, 1-41.

RICHTER 1970

Richter A., "100 Jahre deutsche Slawistik. Teil II: Zur internationalen Ausstrahlung des Leipziger Lehrstuhls unter Leskien: der erste Promovend Jan Baudoin de Courtenay aus Polen," Wissenschaftliche Zeitschrift der Technischen Hochschule Otto von Guericke Magdeburg, 14, 1970, 107-166.

DE SAUSSURE 1972

DE SAUSSURE F., Cours de linguistique générale, publié par Charles Bally et Albert Sechehaye, avec la collaboration de Albert Riedlinger, édition critique préparée par T. DE MAURO, Paris, 1972.

1996

Komatsu E., Wolf G., eds., transl., Premier Cours De Linguistique Générale (1907): D’après les cahiers d'Albert Riedlinger $=$ Saussure's First Course of Lectures on General Linguistics (1907): from the Notebooks of Albert Riedlinger (Relié), 1 (= Language and Communication Library, 15), Oxford, etc., 1996.

2002

DE SAuSSure F., Écrits de linguistique générale, établi et édité par S. Bouquet et R. ENGLER, Gallimard, 2002.

SCHARNHORST/ISING 1976/1982

SCHARNHORST J., IsING E., Grundlagen der Sprachkultur. Beiträge der Prager Linguistik zur Sprachtheorie und Sprachpflege (= Sprache und Gesellschaft, 8.1.2), 1, Berlin, 1976; 2, Berlin, 1982.

SCHмIDT 2007

SchмiDt W., Geschichte der deutschen Sprache. Ein Lehrbuch für das germanistische Studium, 10., verb. u. erw. Aufl., erarb. unter der Leitung v. H. LANGER und N.-R. WoLf, Stuttgart, 2007.

Sснмітт 1999

Sснмітт Сн., "Sprachliche Entwicklung des Französischen als Folge von Soziologisierung und Europäisierung," Sociolinguistica, 13, 1999, 69-90.

SCHUM 1888

SChum W., “Die schriftlichen Quellen,” in: [GröBer 1888A: 157-196].

SINNER 2014

SINNER C., Varietätenlinguistik. Eine Einführung, Tübingen, 2014.

Socin 1888

Socin A., Schriftsprache und Dialekte im Deutschen nach Zeugnissen alter und neuer Zeit. Beiträge zur Geschichte der deutschen Sprache, Heilbronn, 1888.

SONDEREGGER 1983

SONDEREgGer S., "Leistung und Aufgabe der Dialektologie im Rahmen der Sprachgeschichtsschreibung des Deutschen,” in: HSK, 1/2, 1526-1558.

SPILLNER 1987

SPILLNER B., "Style and Register," in: HSK, 3/1, 273-285.

THÈSES 1929

“Thèses [présentées au Premier congrès des philologues slaves]," in: Travaux du Cercle Linguistique de Prague, 1, 1929, 3-29.

Tolstoj 1982

TolstoJ N. I., "Odnos starog srpskog knjiškog jezika prema starom slovenskom jeziku (U vezi sa razvojam žanrova u staroj srpskoj književnosti)," in: Naučni sastanak slavista u Vukove dane, 8/1 (1978), Beograd, 1982, 15-25 (на русском языке: Толстой Н. И. “Отношение древнесербского книжного языка к старославянскому языку”, в: [Толстой 1988А: 164-173]). 
TOMAN 1995

Toman J., The Magic of a Common Language: Mathesius, Jakobson, Trubetzkoy, and the Prague Linguistic Circle (= Current Studies in Linguistics, 26), Cambridge (Mass.), 1995.

Traube 1909

TRAuBe L., Vorlesungen und Abhandlungen, 1: Zur Paläographie und Handschriftenkunde, mit biographischer Einleitung v. F. Boll, München, 1909.

VÁRVARO 1972-1973

VÁRVARO A., "Storia della lingua: passato e prospettive di una categoria controversa," in: Romance Philology, 26/1, 1972, 16-51; 26/3, 1973, 509-531.

VYKYPĚL 2013

VYкYPĚL B., Skizzen zur linguistischen Historiographie (= Travaux linguistiques de Brno, 9), München, 2013.

WILMET 1990

WiLMET M., "Le français: Histoire interne de la langue," in: $L R L, 1,493-507$.

ZARNCKE 1890

ZARNCKE E., Die Entstehung der griechischen Literatursprachen, Leipzig, 1890.

\section{References}

Aitchison J., Language Change: Progress or Decay? 4th ed., Cambridge, etc., 2013.

Alekseev A. A., "Predislovie," in: A. I. Sobolevskiy, Istoriia russkogo literaturnogo iazyka, A. A. Alekseev, ed., Leningrad, 1980, 3-20.

Alekseev A. A., "Kommentarii," in: A. I. Sobolevskiy, Istoriia russkogo literaturnogo iazyka, A. A. Alekseev, ed., Leningrad, 1980, 159-189.

Alekseev A. A., "[Rev.:] Tolstoi N. I. Istoriia i struktura slavianskikh literaturnykh iazykov," Voprosy iazykoznaniia, 4, 1989, 149-155.

Alekseev A. A., Ocherki i etiudy po istorii literaturnogo iazyka v Rossii, S.-Peterburg, 2013.

Albrecht J., "Die Berücksichtigung des Faktors «Übersetzung» in der Sprachgeschichtsschreibung," in: A. Gil, C. Schmitt, Hrsg., Aufgaben und Perspektiven der romanischen Sprachgeschichte im dritten Jahrtausend. Akten der gleichnamigen Sektion des XXVII. Deutschen Romanistentages. München (7.-10. Oktober 2001), Bonn, 2003, 1-20.

Bähler U., Gaston Paris et la philologie romane $(=$ Publications romanes et françaises, 234), Genève, 2004

Baudouin de Courtenay J. N., Dzieła wybrane, 1-4, Warszawa, 1974-1990.

Baum R., Hochsprache. Literatursprache. Schriftsprache: Materialien zur Charakteristik von Kultursprachen (= Impulse der Forschung, 49), Darmstadt, 1987.

Baum R., "Periodisierung in der romanistischen Sprachgeschichtsschreibung," in: G. Ernst, M.D. Gleßgen, Ch. Schmitt, Romanische Sprachgeschichte. Ein internationales Handbuch zur Geschichte der romanischen Sprachen, Bd. 1, Berlin, New York,
2003, 45-52.

Berschin H., "Interne und externe Sprachgeschichte," in: Methodologie (Sprache in der Gesellschaft / Sprache und Klassifikation / Datensammlung und -verarbeitung) (= Holtus G., Metzeltin M., Schmitt Ch., Hrsg., Lexikon der Romanistischen Linguistik, 1/2), Tübingen, 2001, 628-637.

Berschin H., "Synchronie und Diachronie in der romanistischen Sprachgeschichtsforschung," in: G. Ernst, M.-D. Gleßgen, Ch. Schmitt, Romanische Sprachgeschichte. Ein internationales Handbuch zur Geschichte der romanischen Sprachen, Bd. 1, Berlin, New York, 2003, 32-38.

Berutto G., "Sprachvarietät - Sprache (Gesamtsprache, historische Sprache)," in: U. Ammon, N. Dittmar, K.-J. Mattheier, Hrsg., Sociolinguistics. An International Handbook of the Science of Language and Society, Bd. 3.1, Berlin, New York, 2006, 188-195.

Besch W., "Dialekt, Schreibdialekt, Schriftsprache, Standardsprache," in: W. Besch, U. Knoop, W. Putschke, H. E. Wiegand, Dialektologie. Ein Handbuch zut deutschen und allgemeinen Dialektforschung, Bd. 1.1, Berlin, New York, 1982, 961-990.

Blumenthal P., "Der Begriff der externen und internen Sprachgeschichte in der Romanistik," in: G. Ernst, M.-D. Gleßgen, Ch. Schmitt, Romanische Sprachgeschichte. Ein internationales Handbuch zur Geschichte der romanischen Sprachen, Bd. 1, Berlin, New York, 2003, 38-45.

Bolten J., "Deutsche Sprachgeschichte und Wirtschaftsgeschichte," in: W. Besch, A. Betten, O. Reichmann, S. Sonderegger, Hrsg., Sprachgeschichte. Ein Handbuch zur Geschichte der deutschen Sprache und 
ihrer Erforschung, Bd. 2.1, Berlin, New York, 1998, 123-138.

Brang P., Züllig M., Kommentierte Bibliographie zur Slavischen Soziolinguistik, unter Mitwirk. v. K. Brang, 1-3 (= Slavica Helvetica, 17), Bern, etc., 1981.

Brozović D., Standardni jezik. Teorija, usporedbe, geneza, povijest, suvremena zbilja, Zagreb, 1970.

Brunot F., Histoire de la langue française. Des origines à nos jours, 1-13, Paris, Colin, 1966-1972.

Budziak R., Jan Baudouin de Courtenay als Soziolinguist und Sprachsoziologe, Bamberg, 1997.

Bulanin D. M. "Predislovie," in: Slovar' knizhnikov i knizhnosti Drevnei Rusi, 1: XI - pervaia polovina XIV v., Leningrad, 1987.

Bunčić D., Die ruthenische Schriftsprache bei Ivan Uževyč unter besonderer Berücksichtigung der Lexik seines Gesprächsbuchs "Rozmova/Besěda". Mit Wörterverzeichnis und Indizes zu seinem ruthenischen und kirchenslavischen Gesamtwerk (= Slavistische Beiträge, 447), München, 2006.

Bushkovitch P., Religion and Society in Russia. The Sixteenth and Seventeenth Centuries, New York, Oxford, 1992.

Bußmann H., Hrsg., Lexikon der Sprachwissenschaft, 3. Aufl., Stuttgart, 2002.

Carter R. "Literary Language," in: J.-L. Mey, ed., Concise Encyclopedia of Pragmatics, Amsterdam, etc., 1998, 520-522.

Cherepanov M. V., "I. A. Boduen de Kurtene o iazyke kak dinamicheskoi sisteme,” in: K. R. Galiullin, G. A. Nikolaev, eds., II Mezhdunarodnye Boduenovskie chteniia: Kazanskaia lingvisticheskaia shkola: traditsii i sovremennost' (Kazan', 11-13 dekabria 2003 g.). Trudy i materialy, 1, Kazan, 2003, 29-32.

Cherubim D., "Zum Programm einer historischen Sprachpragmatik,” in: H. Sitta, Hrsg., Ansätze $z u$ einer pragmatischen Sprachgeschichte. Zürcher Kolloquium (= Reihe Germanistische Linguistik, 21), Tübingen, 1980, 3-21.

Cherubim D., "Sprachgeschichte im Zeichen der linguistischen Pragmatik," in: W. Besch, A. Betten, O. Reichmann, S. Sonderegger, Hrsg., Sprachgeschichte. Ein Handbuch zur Geschichte der deutschen Sprache und ihrer Erforschung, Bd. 2.1, Berlin, New York, 1998, 538-550.

Coseriu E., "Sinkhroniia, diakhroniia i istoriia," in: Novoe v lingvistike, 3, Moscow, 1963, 143-343.

Coseriu E., "Georg von der Gabelentz et la linguistique synchronique," Word, 23, 1967, 74-100.

Coseriu E., "Gabelentz und die synchronische Sprachwissenschaft,” in: G. von der Gabelentz, Die Sprachwissenschaft, ihre Aufgaben, Methoden und bisherigen Ergebnisse, mit einer Studie v. E. Coserio, 2. Aufl. (= Tübinger Beiträge zur Linguistik, 1), Tübingen, 1972, 3-35.

Coseriu E., “«Historische Sprache» und «Dia- lekt»," in: Energeia und Ergon: Sprachliche Variation - Sprachgeschichte - Sprachtypologie, 1: Schriften von Eugenio Coseriu (= Tübinger Beiträge zur Linguistik, 300), Tübingen, 1988, 45-61.

Coseriu E., Sprachkompetenz: Grundzüge der Theorie des Sprechens, 2., durchges. Aufl., bearb. u. hrsg. v. H. Weber (= Tübinger Beiträge zur Linguistik, 508), Tübingen, 2007.

Daneš F., "Herausbildung und Reform von Standardsprachen," U. Ammon, N. Dittmar, K.J. Mattheier, Hrsg., Sociolinguistics. An International Handbook of the Science of Language and Society, Bd. 3.2, Berlin, New York, 1988, 1506-1516.

Daneš F., "Herausbildung und Reform von Standardsprachen und Destandardisierung," U. Ammon, N. Dittmar, K.-J. Mattheier, Hrsg., Sociolinguistics. An International Handbook of the Science of Language and Society, 3.3, Berlin, New York, 2006, 2197-2209.

De Mauro T., Storia linguistica dell'Italia unita (= Biblioteca universale Laterza, 88), 3rd ed., Bari, 1986.

Devoto G., Storia della lingua di Roma (= Storia di Roma, 23), Bologna, 1940.

Devoto G., I fondamenti della storia linguistica (= Biblioteca enciclopedica Sansoniana, 9), Firenze, 1951.

Di Cesare D., "Einleitung," in: W. von Humboldt, Über die Verschiedenheit des menschlichen Sprachbaues und ihren Einfluß auf die geistige Entwickelung des Menschengeschlechts, hrsg. v. D. di Cesare, Padeborn etc., 1998, 9-128.

Dräxler H.-D., Soziolinguistik, Pragmalinguistik und Sprachgeschichte. Die Bedeutung sozio- und pragmalinguistischer Parameter für eine Theorie des Sprachwandels (= Impulse. Didaktisches Zentrum der Johann Wolfgang Goethe-Universität Frankfurt, 9), Darmstadt, 1989.

Droixhe D., Dutilleul Th., "Le français: Histoire externe de la langue,” in: Französisch, Okzitanisch, Katalanisch (= Holtus G., Metzeltin M., Schmitt Ch., Hrsg., Lexikon der Romanistischen Linguistik, 5/1), Tübingen, 1990, 437-471.

Durnovo N., Ocherk istorii russkogo iazyka (= Slavistische Drukken en Herdrukken, 22), 'S-Gravenhage, 1962.

Ernst G., Gleßgen M.-D., Schmitt Ch., Schweickard W., "Romanistik und Sprachgeschichtsschreibung,” in: G. Ernst, M.-D. Gleßgen, Ch. Schmitt, Romanische Sprachgeschichte. Ein internationales Handbuch zur Geschichte der romanischen Sprachen, Bd. 1, Berlin, New York, 2003, 1-15.

Erofeeva I. V., "Primenenie dikhotomicheskogo printsipa vnutrennei i vneshnei istorii iazyka I. A. Boduena de Kurtene k izucheniiu pamiatnikov drevnerusskoi pis'mennosti," in: K. R. Galiullin, G. A. Nikolaev, eds., Boduenovskie chteniia: Boduen de Kurtene $i$ sovremennaia lingvistika: Mezhdu- 
narodnaia nauchnaia konferentsiia (Kazan', 11-13 dekabria 2001 g.): Trudy i materialy, 1, Kazan, 2001, 68-69.

Flydal L., "Remarques sur certains rapports entre le style et l'état de langue," in: Norsk Tidsskrift for Sprogvidenskap, 16, 1952, 241-258.

Franklin S., Writing, Society and Culture in Early Rus, c. 950-1300, Cambridge, 2002.

Franklin S., Pis'mennost', obshchestvo i kul'tura v Drevnei Rusi: (Okolo 950-1300 gg.), D. M. Bulanin, transl., St. Peterburg, 2010.

von der Gabelentz G., Die Sprachwissenschaft, ihre Aufgaben, Methoden und bisherigen Ergebnisse, mit einer Studie v. E. Coseriu, 2. Aufl. (= Tübinger Beiträge zur Linguistik, 1), Tübingen, 1972.

Gardt A., Haß-Zumkehr U., Roelke Th., Hrsg., Sprachgeschichte als Kulturgeschichte (= Studia Linguistica Germanica, 54), Berlin, New York, 1999.

Giovanardi C., "Soziolinguistik und italienische Sprachgeschichte: einige Betrachtungen zur Debatte im 16. Jahrhundert," Sociolinguistica, 13, 1999, 17-26.

Glück H., Hrsg., Metzler Lexikon Sprache, 3., neubearb. Aufl., Stuttgart, Weimar, 2005.

Golubev I. F., "Vstrecha Simeona Polotskogo, Epifaniia Slavinetskogo i Paisiia Ligarida s Nikolaem Spafariem i ikh beseda," in: Trudy Otdela drevnerusskoi literatury, 26, Leningrad, 1971, 294301.

González C.-H., "Historia lingüística externa,” in: Aragonesisch/Navarresisch, Spanisch, Asturianisch/ Leonesisch (= Holtus G., Metzeltin M., Schmitt Ch., Hrsg., Lexikon der Romanistischen Linguistik, 6/1), Tübingen, 1992, 406-414.

Gorshkov A. I., Teoreticheskie osnovy istorii russkogo literaturnogo iazyka, Moscow, 1983.

Gorshkov A. I., Teoriia $i$ istoriia russkogo literaturnogo iazyka, Moscow, 1984.

Gumperz J.-J., "Types of Linguistic Communities," in: Idem, Language and Social Groups, A.S. Dil, ed., Stanford, 1971, 97-113.

Hafner J., Ferdinand Brunot und die nationalphilologische Tradition der Sprachgeschichtsschreibung in Frankreich (= Romanica Monacensia, 73), Tübingen, 2006.

Havránek B., Studie o spisovném jazyce, Praha, 1963.

Hildenbrandt E., Versuch einer kritischen Analyse des "Cours de linguistique générale" von Ferdinand de Saussure (= Marburger Beiträge zur Germanistik, 36), Marburg, 1972.

Horálek K., "Zur Geschichte der Prager Linguistik und ihrer internationalen Wirkung," in: Scharnhorst J., Ising E., Grundlagen der Sprachkultur. Beiträge der Prager Linguistik zur Sprachtheorie und Sprachpflege (= Sprache und Gesellschaft, 8.1.2), 1, Berlin, 1976, 24-42.

Horrocks G., Greek: A History of the Language and Its Speakers, London, New York, 1997.

Hujer O., Úvod do dějin jazyka českého, druhé vydání, Praha, 1924.

Hujer O., Uvod u istoriju slovenskih jezika, H. Barić, transl. (= Lingvistička biblioteke, 1), Beograd, 1935.

von Humboldt W., Über die Verschiedenheit des menschlichen Sprachbaues und ihren Einfluß auf die geistige Entwickelung des Menschengeschlechts, hrsg. v. D. Di Cesare, Paderborn etc., 1998.

Issatschenko A. V., "Otvet na vopros §3 Ankety k IV MSS,” Voprosy iazykoznaniia, 3, 1958, 42.

Jäger L., "Das Verhältnis von Synchronie und Diachronie in der Sprachgeschichtsforschung," in: W. Besch, A. Betten, O. Reichmann, S. Sonderegger, Hrsg., Sprachgeschichte. Ein Handbuch zur Geschichte der deutschen Sprache und ihrer Erforschung, Bd. 2.1, Berlin, New York, 1998, 816-824.

Jedlička A., Spisovnýjazyk v současné komunikaci, Praha, 1978.

Jedlička A., "Theorie der Literatursprache," in: Scharnhorst J., Ising E., Grundlagen der Sprachkultur. Beiträge der Prager Linguistik zur Sprachtheorie und Sprachpflege (= Sprache und Gesellschaft, 8.1.2), 2, Berlin, 1982, 40-91.

Kamchatnov A. M., Istoriia russkogo literaturnogo iazyka: XI - pervaia polovina XIX veka, Moscow, 2008.

Karskiy E. F., "Glavneishie techeniia v russkom literaturnom iazyke. Vstupitel'naia lektsiia po russkomu iazyku lektora Varshavskogo universiteta E. F. Karskogo, proiznesennaia 27 fevralia 1893 goda," in: Idem, Trudy po belorusskomu i drugim slavianskim iazykam, Moscow, 1962, 130-139.

Keipert H., "Russische Sprachgeschichte als Übersetzungsgeschichte,” in: W. Girke, Hrsg., Slavistische Linguistik 1981. Referate des VII. Konstanzer Slavistischen Arbeitstreffens. Mainz 30.9.2.10.1981 (= Slavistische Beiträge, 160), München, 1982, 67-101.

Keipert H., "[Rev.:] Gorshkov V. I. Teoreticheskie voprosy istorii russkogo literaturnogo iazyka. Moskva 1983," Russian Linguistics, 8, 1984, 159-166.

Keipert H., "Old and New Problems of the Russian Literary Language (Arguments for a New Kind of Russian Linguistic History)," in: W. Girke, D. Worth, eds., The Formation of the Slavonic Literary Languages. Proceedings of a Conference Held in Memory of Robert Auty and Anne Pennington at Oxford 6-10 July 1981 (= UCLA Slavic Studies, 11), Columbus (OH), 1985, 215-224.

Keipert H., "Die Christianisierung Russlands als Gegenstand der russischen Sprachgeschichte," in: K. Ch. Felmy, G. Kretschmar, F. von Lilienfeld, C.-J. Roepke, Hrsg., Tausend Jahre Christentum in Russland. Zum Millennium der Taufe der Kiever Rus', Göttingen, 1988, 313-346.

Keipert H., "Kreshchenie Rusi i istoriia russkogo literaturnogo iazyka," Voprosy iazykoznaniia, 5, 
1991, 86-112.

Keipert H., "A. Chr. Vostokov, die deutsche Slavenkunde und das Altbulgarische," Palaeobulgarica, 20/1, 1996, 99-114.

Keipert H., "Cerkovnoslavjanskij: eine Sprachbezeichnung als Problem der Wortbildungslehre," in: M. Ya. Glovinskaia, ed., Liki iazyka: K 45-letiiu nauchnoi deiatel'nosti E. A. Zemskoi, Moscow, 1998, 143-152.

Keipert H., "A. S. Budilovičs «Obščeslavjanskij jazyk» (1892). Ein Rückblick,” in: K. Grünberg, W. Potthoff, Hrsg., Ars Philologica. Festschrift für Baldur Panzer zum 65. Geburtstag, Frankfurt a. M., etc., 1999, 69-80.

Keipert H., "Die Kirchenslavisch-These des Cercle linguistique de Prague," in: E. Hansack, W. Koschmal, N. Nübler, Hrsg., Festschrift für Klaus Trost zum 65. Geburtstag (= Die Welt der Slaven. Sammelbände, 5), München, 1999, 123-133.

Keipert H., "Geschichte der russischen Literatursprache," in: H. Jachnow, Hrsg., Handbuch der sprachwissenschaftlichen Russistik und ihrer Grenzdisziplinen (= Slavistische Studienbücher, N. F., 8), Wiesbaden, 1999, 726-779.

Keipert H., "«Rozmova/Besěda»: Das Gesprächsbuch Slav. № 7 der Bibliothèque nationale de France," Zeitschrift für Slavische Philologie, 60/1, 2001, 9-40.

Keipert H., "Kirchenslavisch als Konstrukt," Slavia, 70, 2001, 373-381.

Keipert H., "Die romanischen Sprachen in der slavistischen Sprachgeschichtsschreibung," in: G. Ernst, M.-D. Gleßgen, Ch. Schmitt, Romanische Sprachgeschichte. Ein internationales Handbuch zur Geschichte der romanischen Sprachen, Bd. 1, Berlin, New York, 2003, 470-476.

Keipert H., "«Über die Altslawonische Sprache nach Schlözer, mit Anmerkungen von J. D. Dobrovskýs» Schlözer-Kritik im «Slavin» und ihre Folgen," in: V. Vavřínek, H. Gladkova, K. Skwarska, vyd., Josef Dobrovský. Fundator studiorum slavicorum. Př́spěvky z mezinárodní vědecké konference $v$ Praze 10. -13. června 2003, Praha, 2004, 261-269.

Keipert H., "August Ludwig Schlözer i «Słownik języka polskiego» Samuela Bogumiła Lindego," Prace filologiczne, 49, 2004, 169-180.

Keipert H., Das "Sprache"-Kapitel in August Ludwig Schlözers "Nestor" und die Grundlegung der historisch-vergleichenden Methode für die slavische Sprachwissenschaft. Miteinem AnhangJosefDobrovskýs "Slavin"-Artikel "Über die Altslawonische Sprache nach Schlözer" und dessen russische Übersetzung von Aleksandr Chr. Vostokov, hrsg. in Verbindung mit M. Š. Fajnštejn (= Abhandlungen der Akademie der Wissenschaften zu Göttingen, PhilologischHistorische Klasse, 3. Folge, 276), Göttingen, 2006.

Keipert H., "Vostokov i Shletser (O nachalakh sravnitel'no-istoricheskogo metoda v slavianskom iazykoznanii)," Russian Linguistics, 30/3, 2006, 303-319.

Keipert H., "Cerkovnoslavjanskij in verordnetem Vergessen," in: M. Jesenšek, Z. Zorko, Hrsg., Jezikovna predanost. Akademiku prof. dr. Jožetu Toporišiču ob 80-letnici (= Zora, 44), Maribor, 2006, 129-145.

Keipert H., "[Rez.:] Ian Press: A History of the Russian Language and Its Speakers. München: LINCOM Europa 2007. XII, 362 S. (LINCOM Studies in Slavic Linguistics. 26.)," Die Welt der Slaven, 53/1, 202-206.

Keipert H., "Altkirchenslavisch und Kirchenslavisch," in: K. Gutschmidt, S. Kempgen, T. Berger, P. Kosta, Hrsg., Die slavischen Sprachen. Ein internationales Handbuch zu ihrer Struktur, ihrer Geschichte und ihrer Erforschung, Berlin, New York, 2014, 1211-1252.

Keller R., Sprachwandel. Von der unsichtbaren Hand in der Sprache, 3. Aufl., Tübingen, Basel, 2003.

Knoop U., "Das Interesse an den Mundarten und die Grundlegung der Dialektologie," in: W. Besch, U. Knoop, W. Putschke, H. E. Wiegand, Dialektologie. Ein Handbuch zut deutschen und allgemeinen Dialektforschung, Bd. 1.1, Berlin, New York, 1982, 1-23.

Koch P., "Italienisch: Externe Sprachgeschichte I," in: Italienisch, Korsisch, Sardisch (= Holtus G., Metzeltin M., Schmitt Ch., Hrsg., Lexikon der Romanistischen Linguistik, 4), Tübingen, 1988, 343360.

Koeder A., Von Ferdinand de Saussure zu einer formalen diachronischen Semantik (Inauguraldissertation zur Erlangung der Doktorwürde, Konstanz, 1999).

Kolesov V. V., Istoriia russkogo iazyka, Moscow, St. Petersburg, 2005.

Komatsu E., Wolf G., eds., transl., Premier Cours De Linguistique Générale (1907): D'après les cahiers d'Albert Riedlinger $=$ Saussure's First Course of Lectures on General Linguistics (1907): from the Notebooks of Albert Riedlinger (Relié), 1 (= Language and Communication Library, 15), Oxford, etc., 1996.

Kuznetsov P. S., "Predislovie," in: O. Hujer, Vvedenie $v$ istoriiu cheshskogo iazyka, 2nd edition, Moscow, 2004, 3-7.

Labov W., Principles of Linguistic Change, 1: Internal Factors (= Language in Society, 20), Oxford, 1994.

Labov W., Principles of Linguistic Change, 2: Social Factors (=Language in Society, 29), Oxford, 2001.

Leith D., A Social History of English, London, New York, 1997.

Lewandowski Th., Linguistisches Wörterbuch, 5. Aufl., 3 Bde., Heidelberg, Wiesbaden, 1990.

Lüdtke J., "Zu den Aufgaben der spanischen Sprachgeschichtsschreibung," Sociolinguistica, 13, 1999, 27-50.

Mattheir K.-J., "Das Verhältnis von sozialem und 
sprachlichem Wandel," in: U. Ammon, N. Dittmar, K.-J. Mattheier, Hrsg., Sociolinguistics. An International Handbook of the Science of Language and Society, Bd. 3.2, Berlin, New York, 1988, 1430-1452.

Mattheier K. J., "Allgemeine Aspekte einer Theorie des Sprachwandels," in: W. Besch, A. Betten, O. Reichmann, S. Sonderegger, Hrsg., Sprachgeschichte. Ein Handbuch zur Geschichte der deutschen Sprache und ihrer Erforschung, Bd. 2.1, Berlin, New York, 1998, 824-836.

Medyntseva A. A., Gramotnost'v Drevnei Rusi (Po pamiatnikam epigrafiki $X$ - pervoi poloviny XIII veka), Moscow, 2000.

Metzeltin M., Gritzky N., "Sprachgeschichtsschreibung: Möglichkeiten und Grenzen," in: G. Ernst, M.-D. Gleßgen, Ch. Schmitt, Romanische Sprachgeschichte. Ein internationales Handbuch zur Geschichte der romanischen Sprachen, Bd. 1, Berlin, New York, 2003, 15-31.

Milroy J., Linguistic Variation and Change: On the Historical Sociolinguistics of English (= Language in Society, 19), Oxford, 1992.

Moser M., "Kleine Sprachgeschichte des Ukrainischen der mittleren Periode," in: J. Besters-Dilger, Hrsg., Sprache und Literatur der Ukraine zwischen Ost und West, Bern, etc., 2000, 127-144.

Mugdan J., Jan Baudouin de Courtenay (18451929): Leben und Werk, München, 1984.

Narumov B. P., "«Arkhitektura iazyka» v kontseptsii E. Koseriu,” in: O. M. Mungalova, Yu. L. Obolenskaia, Yu. A. Karpova, eds., Voprosy ibero-romanskoi filologii, 7, Moscow, 2005, 140-145.

Nikolaeva T. M., "Nekotorye obshcheteoreticheskie idei iazykovedeniia v trudakh I. A. Boduena de Kurtene," in: K. R. Galiullin, G. A. Nikolaev, eds., II Mezhdunarodnye Boduenovskie chteniia: Kazanskaia lingvisticheskaia shkola: traditsii $i$ sovremennost' (Kazan', 11-13 dekabria 2003 g.). Trudy $i$ materialy, 1, Kazan, 2003, 21-25.

Paul H., Prinzipien der Sprachgeschichte, 5. Aufl., Darmstadt, 1920.

von Polenz P., Deutsche Sprachgeschichte vom Spätmittelalter bis zur Gegenwart, 1: Einführung. Grundbegriffe. Deutsch in der frühbürgerlichen Zeit, Berlin, New York, 1991; 2: 17. und 18. Jahrhundert, Berlin, New York, 1994.

von Polenz P., "Deutsche Sprache und Gesellschaft in historischer Sicht," in: HSK, 2/1, 41-54.

von Polenz P., "Sprachgeschichte und Gesellschaftsgeschichte von Adelung bis heute," in: D. Cherubim, K. Jakob, A. Linke, Hrsg., Neue deutsche Sprachgeschichte. Mentalitäts-, kultur- und sozialgeschichtliche Zusammenhänge (= Studia Linguistica Germanica, 64), Berlin, New York, 2002, $1-23$.

Polivanov E. D., "Istoricheskoe iazykoznanie i iazykovaia politika,” in: V. A. Zvegintsev, Istoriia iazykoznaniia XIX $i$ XX vekov v ocherkakh $i$ izvle- cheniiakh, 2, Moscow, 1960, 263-278.

Polzin-Haumann C., Sprachreflexion und Sprachbewusstsein. Beitrag zu einer integrativen Sprachgeschichte des Spanischen im 18. Jahrhundert (= Bonner romanistische Arbeiten, 91), Frankfurt a. M., 2006.

Press I., A History of the Russian Language and Its Speakers (= LINCOM Studies in Slavic Linguistics, 26), München, 2007.

Reichmann O., "Sprachgeschichte: Idee und Verwirklichung," in: W. Besch, A. Betten, O. Reichmann, S. Sonderegger, Hrsg., Sprachgeschichte. Ein Handbuch zur Geschichte der deutschen Sprache und ihrer Erforschung, Bd. 2.1, Berlin, New York, 1998, 1-41.

Richter A., "100 Jahre deutsche Slawistik. Teil II: Zur internationalen Ausstrahlung des Leipziger Lehrstuhls unter Leskien: der erste Promovend Jan Baudoin de Courtenay aus Polen," Wissenschaftliche Zeitschrift der Technischen Hochschule Otto von Guericke Magdeburg, 14, 1970, 107-166.

de Saussure F., Cours de linguistique générale, publié par Charles Bally et Albert Sechehaye, avec la collaboration de Albert Riedlinger, édition critique préparée par T. de Mauro, Paris, 1972.

de Saussure F., Écrits de linguistique générale, établi et édité par S. Bouquet et R. Engler, Gallimard, 2002.

de Saussure F., Kurs obshchei lingvistiki, A. M. Sukhotin, trans., R. I. Shor, ed., 3d ed., Moscow, 2006.

Scharnhorst J., Ising E., Grundlagen der Sprachkultur. Beiträge der Prager Linguistik zur Sprachtheorie und Sprachpflege (= Sprache und Gesellschaft, 8.1.2), 1, Berlin, 1976; 2, Berlin, 1982.

Schmidt W., Geschichte der deutschen Sprache. Ein Lehrbuch für das germanistische Studium, 10., verb. u. erw. Aufl., erarb. unter der Leitung v. H. Langer und N.-R. Wolf, Stuttgart, 2007.

Schmitt Ch., "Sprachliche Entwicklung des Französischen als Folge von Soziologisierung und Europäisierung," Sociolinguistica, 13, 1999, 69-90.

Sharadzenidze T. S., Lingvisticheskaia teoriia I. A. Boduena de Kurtene $i$ ee mesto $v$ iazykoznanii XIX-XX vekov, Moscow, 1980.

Sinner C., Varietätenlinguistik. Eine Einführung, Tübingen, 2014.

Sobolevskiy A. I., Lektsii po istorii russkogo iazyka, 4th edition (= Slavistische Drukken en Herdrukken, 37), 'S-Gravenhage, 1962.

Sobolevskiy A. I., Istoriia russkogo literaturnogo iazyka, A. A. Alekseev, ed., Leningrad, 1980.

Sonderegger S., "Leistung und Aufgabe der Dialektologie im Rahmen der Sprachgeschichtsschreibung des Deutschen," in: W. Besch, U. Knoop, W. Putschke, H. E. Wiegand, Dialektologie. Ein Handbuch zut deutschen und allgemeinen Dialektforschung, Bd. 1.2, Berlin, New York, 1983, 1526- 
1558.

Spillner B., "Style and Register," in: U. Ammon, N. Dittmar, K.-J. Mattheier, Hrsg., Sociolinguistics. An International Handbook of the Science of Language and Society, Bd. 3.1, Berlin, New York, 2006, 273-285.

Tolstoj N. I., "Odnos starog srpskog knjiškog jezika prema starom slovenskom jeziku (U vezi sa razvojam žanrova u staroj srpskoj književnosti)," in: Naučni sastanak slavista u Vukove dane, 8/1 (1978), Beograd, 1982, 15-25.

Tolstoj N. I., Istoriia i struktura slavianskikh literaturnykh iazykov, Moscow, 1988.

Tolstoj N. I., "Vzgliady A. N. Pypina na istoriiu russkogo literaturnogo iazyka (Stranichka iz istorii russkoi lingvistiki)," in: W. Moskovich et al., eds., Russian Philology and History: In Honor of Professor Victor Levin, Jerusalem, 1992, 156-169.

Toman J., The Magic of a Common Language: Mathesius, Jakobson, Trubetzkoy, and the Prague Linguistic Circle (= Current Studies in Linguistics, 26), Cambridge (Mass.), 1995.

Trubetzkoy N. S., "Obshcheslavianskii element v russkoi kul'ture," in: Idem, Istoriia. Kul'tura. Iazyk, N. I. Tolstoj, L. N. Gumilev, V. M. Zhivov, eds., Moscow, 1995, 162-208.

Uspenskij B. A., "Istoriia russkogo literaturnogo iazyka kak mezhslavianskaia distsiplina," Voprosy iazykoznaniia, 1, 1995, 80-92.

Uspenskij B. A., Istoriia russkogo literaturnogo iazyka (XI-XVII vv.), 3rd edition, Moscow, 2002.

Várvaro A., "Storia della lingua: passato e prospettive di una categoria controversa," in: Romance Philology, 26/1, 1972, 16-51; 26/3, 1973, 509-531.

Vereshchagin E. M., "Problemy istorii drevneslavianskogo i russkogo literaturnogo iazykov (K vykhodu v svet knigi akad. N. I. Tolstogo)," Izvestiia AN SSSR. Seriia literatury i iazyka, 48/2, 1989, 126-136.

Vinogradov V. V., Izbrannye trudy. Istoriia russkogo literaturnogo iazyka, Moscow, 1978.

Vinogradov V. V., Ocherki iz istorii literaturnogo iazyka XVII-XIX vv., Moscow, 1982.

Vinokur G. O., "O zadachakh istorii iazyka," in: Idem, Izbrannye trudy po russkomu iazyku, Moscow, 1959, 207-226.

Vvedenskiy D. N., "Ferdinand de Sossiur i ego mesto v lingvistike," in: R. I. Shor, ed., Kurs obshchei lingvistiki, izdannyi Sh. Bal'i i A. Seshee pri uchastii A. Ridlinger, Moscow, 1933.

Vykypěl B., Skizzen zur linguistischen Historiographie (= Travaux linguistiques de Brno, 9), München, 2013.

Wilmet M., "Le français: Histoire interne de la langue," in: Französisch, Okzitanisch, Katalanisch (= Holtus G., Metzeltin M., Schmitt Ch., Hrsg., Lexikon der Romanistischen Linguistik, 5/1), Tübingen, 1990, 493-507.

Zhivov V. M., Iazyk i kul'tura v Rossii XVIII veka, Moscow, 1996.

Zakharova Yu. G., Istoriia russkogo iazyka. Uchebnoe posobie dlia prakticheskikh zaniatii, Moscow, 2012.

Zhuravlev V. K., Zhuravlev I. V., "Zamechaniia o predmete istorii literaturnogo iazyka," in: E. F. Budde, Ocherk istorii sovremennogo literaturnogo iazyka (XVII-XIX vek), 2nd edition, Moscow, 2005, IIIVIII.

Zvegintsev V., "Teoreticheskie aspekty prichinnosti iazykovykh izmenenii," in: Novoe v lingvistike, 3, Moscow, 1963, 125-142.

\author{
Ирина Александровна Подтергера, канд. филол. наук \\ Slavisches Seminar der Albert-Ludwigs-Universität Freiburg \\ Werthmannstr. 14 \\ 79098 Freiburg im Breisgau \\ Deutschland/Germany \\ irina.podtergera@slavistik.uni-freiburg.de
}

